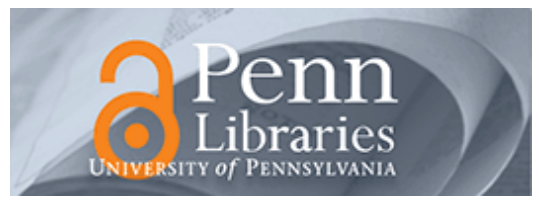

University of Pennsylvania

ScholarlyCommons

Finance Papers

Wharton Faculty Research

2006

\title{
The Real Effects of the Euro: Evidence From Corporate Investments
}

Arturo Bris

Yrjo Koskinen

University of Pennsylvania

Mattias Nilsson

Follow this and additional works at: https://repository.upenn.edu/fnce_papers

Part of the Finance Commons, and the Finance and Financial Management Commons

\section{Recommended Citation}

Bris, A., Koskinen, Y., \& Nilsson, M. (2006). The Real Effects of the Euro: Evidence From Corporate Investments. Review of Finance, 10 (1), 1-37. http://dx.doi.org/10.1007/s10679-006-6977-3

At the time of publication, author Yrjo Koskinen was affiliated with Boston University School of Management and CEPR. Currently, he is a faculty member at the Wharton School at the University of Pennsylvania.

This paper is posted at ScholarlyCommons. https://repository.upenn.edu/fnce_papers/240

For more information, please contact repository@pobox.upenn.edu. 


\title{
The Real Effects of the Euro: Evidence From Corporate Investments
}

\author{
Abstract \\ We study how the adoption of the euro as the common currency in Europe has affected firms' investment \\ rates. Using corporate data from the eleven countries that adopted the euro in January 1999, as well as \\ from a control sample of five other European countries, our paper shows that: (i) the euro has increased \\ investments for firms from countries that previously had weak currencies, (ii) the euro has had a positive \\ impact on financially constrained firms' investments, and (iii) the euro has decreased investments for \\ financially unconstrained firms from countries that previously had strong currencies. \\ Disciplines \\ Finance | Finance and Financial Management

\section{Comments} \\ At the time of publication, author Yrjo Koskinen was affiliated with Boston University School of \\ Management and CEPR. Currently, he is a faculty member at the Wharton School at the University of \\ Pennsylvania.
}




\title{
The Real Effects of the Euro:
}

\section{Evidence from Corporate Investments*}

\author{
Arturo Bris \\ Yale School of Management and ECGI \\ Yrjö Koskinen ${ }^{\dagger}$ \\ Boston University School of Management and CEPR \\ Mattias Nilsson \\ Stockholm Institute for Financial Research
}

May 2005

${ }^{*}$ We thank seminar audiences at SIFR and SITE in Stockholm, the 2004 EFA meetings in Maastricht, Binghamton University, as well as Franklin Allen, Marco Pagano, Michael Schill, and two anonymous referees for helpful comments. An earlier version of the paper constituted a part of the manuscript "The Euro Is Good After All: Corporate Evidence", which was presented at the ECB-CFS workshop in Helsinki. Nilsson acknowledges financial support from Jan Wallander and Tom Hedelius' Foundation. All remaining errors are our sole responsibility.

${ }^{\dagger}$ Corresponding author: 595 Commonwealth Avenue, Boston, MA 02215, USA. Tel: +1-617-353-9775; fax: +1617-353-6667; e-mail: yrjo@bu.edu. 


\begin{abstract}
We study how the adoption of the euro as the common currency in Europe has affected firms' investment rates. Using corporate data from the eleven countries that adopted the euro in January 1999, as well as from a control sample of five other European countries, our paper shows that: (i) the euro has increased investments for firms from countries that previously had weak currencies, (ii) the euro has had a positive impact on financially constrained firms' investments, and (iii) the euro has decreased investments for financially unconstrained firms from countries that previously had strong currencies.

KEYWORDS: Economic and Monetary Union (EMU), the euro, currency union, investments.

JEL classification: F33, F36, G32
\end{abstract}




\section{Introduction}

In this paper we study how the adoption of the euro has affected firms' investment rates in Europe. In January 1, 1999 the Economic and Monetary Union (EMU) entered its final phase when the euro became the common currency for eleven European countries. The introduction of the euro was a momentous event for Europe. On a more mundane level, it provides researchers a rare opportunity to study firm behavior when something as close to exogenous as possible happens. We build on our previous research that shows that the euro has significantly increased corporate valuations for euro-countries that previously had weak currencies (see Bris, Koskinen, and Nilsson, 2003b). The question addressed in this paper is whether and how the increase in corporate valuations has led to an increase in firms' investment rates.

According to the neoclassical theory of investment (see for example, Jorgenson, 1963; Hall and Jorgenson, 1967) a firm invests so that the expected marginal product of investment equals the cost of capital. Everything else constant, a reduction in the firm's cost of capital enlarges the set of profitable investment opportunities and thus increases investments. Similarly, investments increase when the expected cash flows from those investments increase given the cost of capital. Financing is assumed to be readily available and there are no information and agency costs. The Q-theory of investment (pioneered by Tobin, 1969; extended by Hayashi, 1982) is another way of expressing the neoclassical theory. According to the Q-theory, the market value of the firm's capital divided by its replacement cost summarizes a firm's investment opportunities. The ratio, Tobin's Q, is a sufficient statistic to explain a firm's investment behavior. In empirical work in corporate finance, Tobin's Q is typically proxied by the firm's market-to-book -ratio.

In our earlier paper we show that Tobin's Q for firms in the euro-countries with a history of recent currency crises increased by 8.7 percent relative to firms in the non-euro countries after the introduction of the euro. The euro-countries that had stable currencies did not experience a significant increase in corporate valuations. The countries that had experienced major currency depreciations are the countries

that were expected to have significant currency risk premia prior to 1998 and hence higher cost of capital. 
Furthermore, we documented a significantly higher increase in valuation - 15.9 percent - for firms coming from the weak currency countries that had an exposure to intra-European currency risks prior to the introduction of the euro. Firms that were harmed by currency depreciations drive this valuation effect. For those firms, the increase in Q induced by the common currency is 22.2 percent.

There are two channels through which valuations have increased in the euro area after 1998. Our own work (Bris et al., 2003b) concludes that value increases among firms in the euro-countries are consistent with a reduction in the cost of capital. In line with our view, Bartram and Karolyi (2003) show that the market risk has become lower for euro firms with significant exports to the euro area. In addition, Hardouvelis, Malliaropoulos, and Priestley (2004) show that deepening financial integration in Europe prior to the introduction of the euro already resulted in lower cost of capital. The second reason why valuations have increased, keeping the cost of capital constant, is increases in expected cash flows. There is a vast literature that argues that common currencies have a positive impact on trade within the currency area and that ultimately the increase in trade leads to higher incomes. ${ }^{1}$ Whatever the channel is, the euro

\footnotetext{
${ }^{1}$ Rose (2000) and Glick and Rose (2002) argue that common currencies have an enormous impact on bilateral trade flows between countries that share the same currency. Rose and van Wincoop (2001) estimate that the euro would increase intra-European trade by 50 percent and Frenkel and Rose (2002) further argue that every 1 percent increase in trade would lead to $1 / 3$ percent increase in income per capita. Thus the introduction of the euro could increase European incomes per capita between 15 and 20 percent. Recent evidence shows that trade effects of the euro are statistically and economically significant, but not as large as the earlier estimates. Micco, Stein, and Ordóñez (2003) estimate that the euro has increased trade between 4 percent and 16 percent among the euro-countries without any evidence of diverting trade from other countries. Barr, Breedon, and Miles (2003) obtain a higher estimate, 29 percent, for the increase in trade among the euro-countries, whereas Bun and Klaassen (2002) find that the euro has increased trade by 4 percent initially and the estimated increase in the long-run would be 40 percent. However, even if the estimated trade effects led to significant increases in national incomes, corporate profits would not necessarily increase by the same amount, if at all. Friberg (2001) develops a model, where firms have a larger incentive to price discriminate between different markets the higher is the variability of the real exchange rate. The reduction of real exchange rate variability through the introduction of the euro would then lead to further goods market
} 
has increased firm valuations and hence may have consequently increased corporate investments as well.

There is also another channel through which the euro may have increased corporate investments. According to the neoclassical theory, there is no difference in cost of capital between funds internal to the firm and funds raised from the external capital markets. Thus the amount of internal funds available to the firm should play no role in investment decisions, controlling for investment opportunities. Empirical research, however, has demonstrated that internal funds available to the firm do matter. Such literature has typically focused on cross-sectional regressions of investment on measures of cash flows controlling for investment opportunities. The method to identify an economic relationship between investment and cash flows has consisted of comparing the coefficient of the cash flow measure for groups of firms with different characteristics (Fazzari, Hubbard, and Petersen, 1988; Whited, 1992; Hoshi, Kashyap, and Scharfstein, 1991) or for the same firms in different subperiods (Gertler and Hubbard, 1988; Kashyap, Lamont, and Stein, 1994). The basic result from all these studies is that internal cash has a positive impact on firms' investments when firms do not have easy access to other sources of capital. ${ }^{2}$

Therefore, the euro may have affected firm investments through changes in financial constraints that firms face. Guiso, Jappelli, Padula, and Pagano (2004) argue that European financial integration has improved some firms' and countries' access to financing. The euro - through the creation of a more integrated financial market - can relax financing constraints in two ways: firms have now easier access to financial markets in other European markets that can be more developed than their domestic financial market, and

integration and lower profits for firms, perhaps offsetting the effects from increased trade.

\footnotetext{
${ }^{2}$ Alternatively, several papers have analyzed the relationship between cash flow and investment by identifying an exogenous shock to cash flows, and comparing the change in investments for different firms as a reaction to the shock. In particular, Blanchard, López de Silanes, and Shleifer (1994) show that firms that receive cash windfalls tend to invest in negative NPV projects, particularly acquisitions. Lamont (1997) analyzes the investment response of oil companies to a drop in oil prices, and shows that firms reduce investments in both their oil and non-oil segments.
} 
regulatory harmonization and competitive pressures can lead to more developed domestic financial markets. One indication of improved financial development in Europe is the large increase in corporate bond issues for firms from euro-countries (see Rajan and Zingales, 2003; Pagano and von Thadden, 2004). Before the introduction of the euro even the largest European companies were dependent on bank financing. Now there is a viable alternative to that and hence potential hold-up problems associated with bank financing should be less severe. If the introduction of the euro has improved access to financing, then the empirical implication is that those firms that were previously more financially constrained should experience the largest increase in investments after controlling for investment opportunities.

In this paper our objective is to study if firms in the euro-area have increased investments compared to firms coming from other European countries and if investments have increased, have they increased in line with the increases in valuations. The core of our empirical analysis consists of estimating investment regressions using the standard controls - measures of profitability, leverage, size - with Tobin's Q, and time dummies for firms in the euro area for the time the common currency has been in use. Because Tobin's $\mathrm{Q}$ is endogenous, we instrument $\mathrm{Q}$ using past variability in $\mathrm{Q}$ values and past levels of interest rates as instruments with the euro-time dummies used as explanatory variables for $\mathrm{Q}$. If $\mathrm{Q}$ is a sufficient statistic for investments, the coefficients on the euro-time dummies should be significant only in the $\mathrm{Q}$ regression. If in addition the euro has affected firms' financial constraints, the euro-time dummies should also explain investments directly in the second stage regression. The reason is that although $\mathrm{Q}$ is a function of financial constraints as well, the relaxation of financial constraints should have a direct effect on investments, irrespective of Q.

Our sample consists of 1, 401 firms from 16 European countries in the period 1994-2002. In particular, we use corporate-level data from eleven countries that adopted the euro. We exclude Greece because it adopted the euro in January 1, 2001 and therefore it would be difficult to classify in our sample. As our control sample we use the three EU countries that did not adopt the euro-Denmark, Sweden, and 
the U.K. - as well as Norway and Switzerland. Using a control sample allows us to compute differencesin-differences estimators to measure the impact of the euro both cross-sectionally and in the time-series domain. We measure investments as total investments during a year divided by the beginning of the period book value of non-cash assets.

We show that the introduction of the euro has had a positive indirect effect on investments through the increase in Q but that effect is offset by the euro's negative direct effect on investments. However, when we split the sample of euro firms between firms in weak-euro countries - countries that suffered a currency crisis in the years before the introduction of the euro - and strong-euro countries, we find that for the weak euro-countries investments increase by 2.2 percent indirectly through the increase in $\mathrm{Q}$ and that the euro has no direct effect on investments. For the strong-euro countries, the situation is the opposite: no significant indirect effect through increase in Q but investments decrease by $1.4-1.7$ percent because of the direct negative effect the euro has on investments. We further show that the increases in investments - through the indirect mechanism of increases in $\mathrm{Q}$ - are larger for firms whose stock prices tended to decline when their domestic currency depreciated against the euro.

To summarize, we find that firms from the weak-euro countries have experienced increases in investments corresponding to increases in Q. However, some firms from strong euro-countries - especially small, domestic companies - have experienced a decrease in their investment rates that is not captured by a decrease in $\mathrm{Q}$. To examine this issue further we divide the firms in our sample into financially constrained and financially unconstrained firms. We show that while all firms in weak-euro countries invest more, the increase in investments is larger for financially unconstrained firms. This is due to the high indirect effect on investments of an increase in Q for those firms. However, constrained firms increase investments more than the increase in their Q would suggest. Hence the euro also has a significant direct effect on investments for financially constrained firms. This is evidence that financial constraints have been relaxed in countries that previously had weak currencies. 
For the strong countries the situation is more complex. There is no indirect or direct euro effect for the constrained firms in strong-euro countries. However, when these firms issue bonds, they experience both an indirect and direct increase in investments. This is evidence that the euro has increased access to financing in strong-euro countries as well. For financially unconstrained firms in the strong-euro area, we document a significant negative direct effect on investments without a corresponding decrease in Q. The most plausible explanation for this is that firms in strong-euro countries operating in domestic markets (nonmanufacturing firms) are restructuring - cutting capacity for example - and hence decreasing investments. The financial markets do not mind this at all so there is no preceding decline in Q. We find support for this last argument when we estimate the $\mathrm{Q}$ and investments regressions industry by industry. Finally, the negative consequences of the euro on investments for the strong countries disappear after France and Germany are dropped out from the sample.

Our paper proceeds as follows. Section 2 describes our data sources and the main variables used throughout the paper. Section 3 describes our main result. In section 4 we extend the results by classifying firms according to the strength of their legacy currency, exchange rate exposure, and firm size. In section 5 we examine the role of financial constraints. In section 6 we provide some robustness tests, and section 7 concludes.

\section{Description of data}

\subsection{Sample selection and data sources}

In order to investigate the effects of the euro on corporate investments we collect firm-level data from all countries that adopted the euro (except Greece) as well as from five Western European countries that did not adopt the euro (Denmark, Sweden, the U.K., Norway, and Switzerland). The latter five countries are either part of the EU (Denmark, Sweden, and the UK) or have bilateral agreements with the EU (Norway 
and Switzerland) that give them more or less full access to the internal market of the EU. Thus, by using this group of countries as a benchmark we are likely to keep effects from general market integration in Europe fixed across firms over time, and enables us to better isolate the effects of the euro on corporate investments. The sample of firms is drawn from Worldscope and covers the time period 1995-2002. We exclude Greece, as Greece did not adopt the euro until January 2001 and it is hard to classify it as either a euro-area or a non-euro-area country in the time period from the introduction of the euro until they actually adopted the common currency.

For our 16 sample countries we include all firms that have complete data on our investment measure and main control variables for the whole time period of 1995-2002. We impose this requirement because we want to analyze within-firm changes following the introduction of the euro and thus need firms to exist both before and after the introduction of the euro.

Our final sample consists of 1, 401 firms (11,208 observations): 713 firms (5,704 observations) from the euro-countries and 688 firms (5,504 observations) from the non-euro countries. Our sample of firms includes public firms only. Therefore our results below do not necessarily apply to privately held firms. ${ }^{3}$

All firm-level data in this study are from Worldscope unless otherwise stated. All macro variables that we employ as control variables in our analyses are from OECD's statistical databases, except for the U.S. dollar exchange rates, which are gathered from EcoWin.

We use the official adoption of the euro in year 1999 as the benchmark year for post-euro time. Bris, Koskinen and Nilsson (2003b) use the year 1998 as the benchmark year for adoption of the euro because that paper focuses on the valuation effects of the new common currency and valuation measures based on market values are forward looking. Arguably, real variables like investments react more slowly to exogenous shocks than stock prices do. In Section 6.6.1 we check the robustness of our assumption.

\footnotetext{
${ }^{3}$ It is possible that the effects of the euro, through its impact on capital markets, has been more significant in public companies, in which case our paper overstates the true effects of the common currency on the entire corporate sector.
} 


\section{[Insert Table 1: Sample Description]}

Table 1 summarizes the characteristics of the sample. ${ }^{4}$ The average firm in our sample has sales of $€ 2.2$ billion, of which 13.6 percent are foreign sales. Average firm Q measured by the market-to-book ratio is 1.5 (1.4 in euro-countries, 1.6 in non-euro countries). The average firm in the euro area is larger than the average firm in the non-euro area (although the difference is not statistically significant). Table 1 also reports average exchange rate betas whose calculation is described in Appendix C. Because firms with foreign assets have positive exchange rate betas, our initial results show that the average euro firm is more likely to be a net exporter to other euro countries, while the average non-euro firm is likely to be a net importer with respect to euro countries or else receives financing in euros. Over the entire sample period, short-term interest rates and term spreads are not statistically different in two areas (short-term interest rate is 4.8 percent and the term-spread is 1.4 percent on average for the whole sample). However euro-countries grow more (3.6 percent GDP growth) than non-euro countries (2.9 percent GDP growth on average).

\subsection{Corporate investment measure}

As a measure of corporate investment, we use the total corporate investments during the year, divided by the beginning-of-period book value of non-cash assets. Corporate investments include: Net Assets from Acquisitions (Worldscope item \#04355), Capital Expenditures (Worldscope item \#04601), Addition to Other Assets (Worldscope item \#04651), and Research and Development (Worldscope item \#01201). Not-cash Assets are calculated as Total Assets (Worldscope item \#02999) minus Cash and Equivalents (Worldscope item \#02001). The investment ratio is measured in domestic currency. Our investment measure includes investment in intangibles. Moreover, it does not exclude depreciation so it is a gross

\footnotetext{
${ }^{4}$ Appendix A lists and describes the variables used in the paper.
} 
figure. Because some firms grow at extreme rates, we winsorize the corporate investment measure at the 99th percentile values for the whole sample in order to reduce the influence of these extreme observations.

As a first indication of the impact of the euro on corporate investments, Table 2 reports the mean and median level of investments in the pre-euro time period (1995-1998) and the post-euro time period (1999-2002) both for euro and non-euro firms. Appendix B details these measures by country. Table 2 also presents mean and median pre- and post-euro investments for euro-countries split into weak- and strong-euro countries, respectively, depending on the strength of their currencies prior to the introduction of the common currency. Weak-euro countries are defined as those that suffered a currency crisis in the years before the introduction of the euro (Finland, Ireland, Italy, Portugal, and Spain). ${ }^{5}$ The other euroarea countries (Austria, Belgium, Germany, France, Luxembourg, and Netherlands) did not experience significant currency depreciations during the European Monetary System crisis in early 1990s - hence the label strong-euro countries. The classification into weak- and strong-euro countries is important, because Bris et al. (2003b) show that weak-euro firms experience a significant increase in their valuations after the introduction of the euro, as opposed to strong-euro firms, which do not show any significant increase in their valuations. Higher valuations should of course in turn lead to increased investments. Notice that the labels of weak- and strong-euro countries only apply to the weakness and strength of the currencies prior to the introduction of the euro and not to the overall economic performance of the respective countries.

\section{[Insert Table 2: Investment Measure]}

In the pre-euro period, investment rate in the non-euro area is 17.3 percent on average per year which is

\footnotetext{
${ }^{5}$ In the autumn of 1992 a wave of speculative attacks hit the European exchange rate mechanism (ERM) and its periphery. Before the end of the year, five countries (Finland, Italy, Norway, Sweden, and the U.K.) had floated their currencies. Despite attempts by a number of countries to remain in the ERM with the assistance of devaluations (Ireland, Portugal, and Spain), the system was unsalvageable.
} 
significantly higher than in the euro-area (14.2 percent mean rate, significantly different at the one percent level). Within the euro-area, investment rates are larger in strong countries (14.9 percent) than in weak countries (12.2 percent) and the difference between the two groups is statistically significant from zero (t statistic is 3.2 ).

In the post-euro period, the pattern is very similar, although we do not find significant differences between weak- and strong-euro countries. Relative to the pre-1999 period, investments in Europe decrease overall and the decline is lower in euro-countries ( -3.8 percent change in investment rates, significantly different from zero) than in non-euro countries (-5.0 percent change, significantly different from zero). The difference between the two figures is statistically significant at the five percent level. Moreover, investment rates decline more in strong-euro countries ( -4.3 percent change) than in weak-euro countries (-2.3 percent change). Of course these numbers ignore cross-sectional differences in firm size, profitability, and investments opportunities which can only be uncovered in panel regressions.

\section{$3 \quad$ Firm investments and the introduction of the euro}

\subsection{Methods}

In the standard Q-theory of investment, a value-maximizing firm will invest as long as the shadow value of an additional unit of capital - the marginal Q - exceeds unity. The model assumes away taxes and capital market imperfections and has the advantage that Q controls for the market evaluation of the firm's investments opportunities (Hayashi, 1982; Fazzari et al., 1988). Therefore, Q is a sufficient statistic for investments as long as one takes into account measurement errors and endogeneity in the calculation of Q. Several empirical papers have shown that Q does not capture all relevant information about the expected future profitability of investments, especially when firms face financial constraints (Fazzari et al., 1988), while others have documented systematic measurement errors in Q (Erickson and Whited, 2000). 
Our econometric specification is based on the standard investment equation where investments depend on $\mathrm{Q}$ and other controls that measure firm's future investment opportunities. We use dummy variables to quantify the impact of the common currency on firms' investments. We recognize that $\mathrm{Q}$ is endogenous. Bris, Koskinen and Nilsson (2003b) find that companies in the euro area experience significant increases in Tobin's Q after 1998 relative to non-euro companies. We therefore estimate a fixed-effects panel regression model with instrumental variables for the 1994-2002 time period. The dependent variable is investments, measured as total investments divided by non-cash assets. The impact of the euro is measured using three different dummy variables. The first dummy variable, "Euro country $\times$ post-euro time period", takes the value one for firms in the euro-countries for years 1999-2002 and zero otherwise. Similarly, we construct two dummy variables indicating firms in the strong- and weak-euro countries, respectively, for the posteuro time period ("Strong-euro country $\times$ post-euro time period" and "Weak-euro country $\times$ post-euro time period"). More formally, let $I_{i c t}$ be investment rate for firm $i$ in country $c$ in year $t$, and $E U R O_{c t}$ be the dummy variable(s) indicating whether the euro was adopted or not by country $c$ in year $t$. We then estimate the following regression model with OLS using annual observations:

$$
I_{i c t}=Y_{t}+F_{i}+\beta \cdot X_{i c t}+\gamma \cdot M_{c t}+\delta \cdot E U R O_{c t}+\mu \cdot Q_{i t-1}+\varepsilon_{i c t},
$$

where $Y_{t}$ is the fixed time effect for year $t, F_{i}$ is the fixed firm effect for firm i, the set $X_{i c t}$ represent time varying firm characteristics, and the set $M_{c t}$ represents time-varying country characteristics. The effect of the euro is estimated in $\widehat{\delta}$.

We estimate equation (1) with instrumental variables, where we instrument the firm-specific $Q$ using euro dummies, firm-specific characteristics and country-specific characteristics in the following way:

$$
Q_{i t}=Y_{t}+F_{i}+\pi \cdot X_{i c t}+\varphi \cdot M_{c t}+\tau \cdot E U R O_{c t}+\psi \cdot Z_{i c t}+\eta_{i c t}
$$

In our baseline 2SLS-specification we use the absolute change in the logarithm of the firm's Q and the 
absolute change in the logarithm of the industry's Q - all lagged - as instruments in $Z_{i c t}$. Changes in Q measure the variability in firm's investment opportunities that are exogenous to investments if markets incorporate their effect in the last year's Q. Changes in Q also proxy for the cost of adjustment of past investment to Q which are incorporated into current values of Q (see Hayashi and Inoue, 1991). ${ }^{6}$

One of the most important trends in Europe in the 1990's was a reduction in interest rates, especially for the weak-euro countries. Prior to the introduction of the euro, the weak-euro countries suffered from credibility problems in their monetary policies resulting in high real interest rates. In addition, the Maastricht Treaty of 1992 established criteria to join the EMU which included reduction in inflation rates, bond yields and government deficit. Therefore we also estimate an additional specification of the 2SLS investment regression including the changes in interest rates. Moreover, while current changes in interest rates and term spread should be related to investment rates, the past values should not. Therefore we can use the past values of interest rates as additional instruments for last year's Q. More specifically, when we estimate the investment regression including the interest rates we use the changes from $t=-1$ to $t=0$ in the 6-month risk free rate and term spread (10 year government bond rate minus the 6-month T-bill rate) for each country as explanatory variables and the lagged levels of these variables as additional instruments for Q.

We also control for a set of macroeconomic variables. As a measure of a country's economic development, we control for the lagged growth rate in real GDP and the lagged log of GDP per capita (in constant euros). Additionally, we control for the relative change in domestic currency with respect to the U.S. dollar. The

\footnotetext{
${ }^{6}$ In all of our tables, we report a Hansen-Sargan test of overidentifying restrictions. The joint null hypothesis is that the instruments are valid instruments, i.e. uncorrelated with the error term and that the excluded instruments are correctly excluded from the estimated equation. Under the null, the test statistic is distributed as chi-squared in the number of overidentifying restrictions. A rejection casts doubt on the validity of the instruments. In all cases we fail to reject the null hypothesis at reasonable levels of confidence.
} 
reason is that one main argument for the U.K. not joining the euro was that U.K. firms are more exposed to risks with the dollar than with the euro. By controlling for the domestic currency/dollar exchange rate, we capture the level of firm investment that is driven by the exposure to the dollar. The yearfixed effects capture common time trends across both euro- and non-euro firms. By using firm-fixed effects, we simultaneously control for both constant country factors (e.g., taxation, accounting rules, legal environment) and for constant firm factors (e.g., industry effects). Furthermore, because we use fixed effects, estimators will be based on the time-series, within-firm variation in variables. Since the objective of our study is to investigate whether there is a regime-switch in firms' investment activities after the introduction of the euro, fixed effects regressions seem particularly suitable. ${ }^{7}$

The euro can affect investments through two different channels: by increasing firms' investment opportunities (in which case we expect the coefficients $\tau$ and $\mu$ to be positive and significant); and by relaxing financial constraints, in which case we expect $\tau$ and $\mu$ to be positive and significant, but also $\delta$ to be significantly different from zero. The reason is that relaxation of financial constraints should affect $\mathrm{Q}$ and then investments, but should also have a direct effect on investments which is not captured by Q. In that sense, a test of whether $\delta$ is statistically significant from zero is a test of the null hypothesis that the euro has affected financial constraints for euro firms.

\subsection{Main results}

In Table 3 we report the results of panel regressions of our measure of investments on a set of explanatory variables. Detailed definitions of all variables used can be found in the Appendix A. We first control for firm-specific characteristics that are well-known to determine a firm's investment policy: profitability, measured by cash flow divided by total assets (Kaplan and Zingales, Fazzari et al., 1988, McConnell and Servaes, 1990); and leverage, measured by total debt to total assets (Myers and Majluf, 1984). Both

\footnotetext{
${ }^{7}$ Following Bertrand, Duflo, and Mullainathan (2004) we cluster standard errors by country.
} 
variables are lagged. We also control for the ratio of cash holdings to total assets. Several papers have shown a positive relationship between cash holdings and investment (Lamont, 1997; Gertler and Hubbard, 1988; Kashyap, Lamont, and Stein, 1994). We also control for the size of the firms by including the log of total sales (in thousands of euros). Finally, we control for Tobin's Q, which is measured as firm specific, instrumented Q. We first report results on the first-stage regressions (regressions 1 and 3) and then the results for the investment equation (regressions 2 and 4).

Table 3 provides regression results for two specifications depending on whether we control for interest rate variables. Profitability and cash holdings are positively and significantly related to investments; more levered firms, and larger firms, invest less. Finally, corporate investments are unrelated to macro variables once we control for firm-fixed effects. We confirm a positive relationship between firm's Q and corporate investment. A 100 percent increase in Q is associated with a 12.8 percent increase in investments (significant at the one percent level). In the first-stage regression, we find several variables to determine Q: profitability $(+)$, cash holdings $(+)$, GDP growth $(+)$, the relative change in domestic/USD exchange rate $(-)$, and the absolute change in $\log (\mathrm{Q})$ in the previous period $(+)$. The interpretation of the last two coefficients is that firms are more valuable in a country the stronger the currency, and that the variability in investments opportunities is associated with higher firm value. Moreover, our results are consistent with Bris, Koskinen and Nilsson (2003b): the euro is associated with a significant increase in firms' Q of 9.9 percent (significant at the five percent level).

Overall, and without controlling for changes in interest rates in the $\mathrm{Q}$ equation, the increase in $\mathrm{Q}$ translates into an increase in firms' investments of 1.27 percent (9.9 percent of 12.8 percent). However, the direct effect of the euro on investments cancels out the indirect increase of the euro on investments through Q.

[Insert Table 3: Main Regression: Investments and the Euro] 
Without controlling for interest rates, the euro dummy has a significant coefficient of -0.012 in the investment equation (equation 2) which means that through its effect on market frictions - possibly financial constraints - the euro has reduced firm investments by 1.2 percent. This direct effect disappears, however, when we control for changes in interest rates. When we control for interest rates in the instrumental equation, the indirect effect of the euro becomes insignificant since the effect of the euro on Q is marginally insignificant. These results imply that for the overall sample the euro has not had any impact on investments when the changes in interest rates are controlled for. Interest rates are a major part of cost of capital and hence also should play a major role in determining Q. We conjecture that the direct effect also becomes insignificant because interest rates are associated with the availability of external financing and therefore with the impact of financial constraints on firm investments. Section 5 analyzes such relationship.

In the next sections we analyze these results in detail. First, we classify countries and firms depending on specific characteristics to determine whether the euro has had a differential effect in any of these subgroups. Then we study the impact of financial constraints on investments to determine whether the significance of the euro dummy in the investment regression is associated with a change in financial constrains for firms in the euro area.

\section{Investments and firm characteristics}

\subsection{Strong-euro vs. weak-euro countries}

We first analyze the effect of the euro for the two groups of countries with weak currencies ("weak-euro countries") and strong currencies ("strong-euro countries"). These results are in Table 4. In weak-euro countries, the euro is associated with increases in investments of 2.2 percent $(0.173 \times 0.126)$, relative to non-euro countries (results are similar when we control for changes in interest rates). Relative to the average rate in Table 2, this means that the euro accounts for 22 percent of the investment rate in weak-euro 
countries after 1998. Moreover, we do not find any direct effect of the euro on investments in weak-euro countries. The euro affects investments only through the increases in Tobin's Q.

\section{[Insert Table 4: Weak vs. Strong euro Countries: Investment and the Euro]}

The results are reversed for strong-euro countries. Consistent with Bris et al. (2003b), Tobin's Q is unrelated to the euro for firms in the strong-euro area. However, once we control for Q, investment rates are negatively affected by the euro in these countries (significant coefficient of -0.017 when we do not control for interest rates and -0.014 when we do). This reduction represents about 16 percent of the investment rate in strong-euro countries after 1998.

Our results in this section show that for the weak-euro countries the indirect positive effect through an increase in $\mathrm{Q}$ is the dominant euro effect. This is consistent with a reduction of the cost of capital and an increase in investment opportunities being the ultimate causes for increased investments for firms in the weak-euro countries. These are the countries for which an elimination of intra-European currency risks was deemed to be ex ante most beneficial. With respect to strong-euro countries, our results document a negative direct euro effect. Potential reasons for this result could be that financing is harder to get or alternatively that some firms are reorganizing and thus reducing investments. We later study more closely the reasons behind this result by examining the role of financial constraints.

\subsection{Results by size}

Our next step is to determine which firms benefit the most from the euro. Bartram and Karolyi (2003) show that large firms have benefitted more from European monetary integration in terms of reduction in market risk. Dahlquist and Robertsson (2001) and Kang and Stulz (1997) also show that large firms benefit more from financial market integration because foreigners tend to invest in large firms. As a result large firms' investor base increases and cost of capital decreases. 
We classify firms in our sample based on the value of total sales in 1997 and compare that value to the median sales within each country. There are 5,640 observations in the group of small (at or belowmedian) firms and 5,568 observations in the group of large firms. We replicate our investment regressions in Table 5 where we interact the euro dummies with dummies for firm size. We provide tests of differences in coefficients.

\section{[Insert Table 5: Small vs. Large Firms: Investment and the Euro]}

We find that for small firms in general - irrespective of euro membership - Q decreases by 4.5 percent after 1998. However, for small firms in weak-euro countries the euro increases Qs by 14.1 percent ( 0.186 minus 0.045$)$ compared to non-euro firms and by 18.6 percent compared to similar small firms in non-euro countries. These increases correspond to an indirect increase in investments of 1.7 percent (compared to all non-euro firms) and 2.3 percent (compared to small non-euro firms). Large firms in weak-euro countries experience an increase in Qs of 15.8 percent which corresponds to an indirect 2.0 percent increase in investments relative to similar non-euro firms. Differences between small and large firms in weak-euro countries are not significantly different from zero. Firms in weak-euro countries fare better than firms in strong-euro countries overall (differences are significantly different from zero).

Consistent with earlier results, the effect of the euro for weak-euro firms is fully captured by increases in Q. However, for strong-euro firms investment is directly negatively related to the euro. This negative effect is more pronounced for small firms. In principle the negative direct effect could happen because of increased difficulties in getting financing or that firms are reorganizing and cutting capacity and thus do not need to invest that much.

To summarize this section, we find that, irrespective of size, firms in weak-euro countries increase investments more than similar firms outside the euro-area. These increases in investments reflect increases in market valuations. In addition, once we control for firm's Q, we still find that small firms in strong-euro countries reduce investments after 1998 relative to non-euro countries. 


\subsection{Results by exchange rate exposure}

The positive effect of the euro on investments for firms in the weak-euro countries is consistent with a real impact of the removal of exchange rate risks since firms in these countries are ex ante firms for which the elimination of currency risks is the most valuable. In this section we directly classify firms depending on their exposure to currency risk and replicate the investment regressions.

We measure exchange rate exposure by calculating the sensitivity of a firm's stock price to fluctuations in the domestic currency with respect to the synthetic euro. We estimate exchange rate betas (ERBs) with a two-factor model where the other factor is the market return ${ }^{8}$. We estimate ERBs using monthly data from January 1992 to December 1994. We deliberately choose an estimation period that is before our sample period in order to avoid potential endogeneity problems. We classify firms into three groups depending on the sign and significance of their ERB estimates. Negative ERB firms' (146 firms, 9.6 percent of the sample) stock returns are negatively affected when the domestic currency depreciated with respect to the euro and positive ERB firms' (73 firms, 4.9 percent of the sample) stock returns are positively affected when the domestic currency depreciated with respect to the euro. The third group of firms (1,269 firms, 85.5 percent of the sample) did not have any significant exchange rate exposure.

We expect firms with negative ERBs to benefit more from the euro since all the large and sudden changes in exchange rates within Europe have been devaluations and hedging against large and sudden exchange rate changes is either very expensive or practically impossible.

\section{[Insert Table 6: Negative vs. Positive ERB: Investments and the Euro]}

We find that, among firms in strong-euro countries, the euro is associated with an additional decrease in market valuations for firms with positive exposure to exchange rate changes (exporting firms). The overall effect, however, is zero when we take into account the small positive valuation effect for all strong-

\footnotetext{
${ }^{8}$ The calculation of exchange rate betas is described in detail in Appendix C.
} 
euro firms. Conversely, firms with negative exposure (importing firms) increase in value after 1998. The results are similar for exposed weak-euro firms, although the coefficient for positive ERB firms is not significantly different from zero. Economically, the effects of the euro depending on currency exposure are high in magnitude: among strong-euro firms, firms with positive exposure reduce investments by 0.8 $(-0.061 \times 0.135)$ percent (from Table 2 strong-euro firms reduce investments 4.3 percent after 1998 so 19 percent of such reduction is due to the elimination of currency risk). Firms with negative exposure increase investments 0.6 percent (relative to a total reduction in investments of 4.3 percent). With respect to firms in weak-euro countries, negative ERB firms increase investments 0.7 percent relative to other weak-euro firms. Moreover, the difference between strong- and weak-euro countries is significant for firms with positive exposure, and for firms with negative exposure. Therefore, reinforcing the results in section 4.4.2, the increase in investments is larger for firms that we expect ex ante to benefit the most from the elimination of the possibility to devalue: firms in weak-euro countries and also those firms which are harmed by currency depreciations.

Once we control for Q, we find a negative direct impact of the euro on investments for those strongeuro firms that have no significant exchange rate exposure. These firms are purely domestic firms with no exposure to foreign markets or alternatively firms that have hedged their exposure. The decline in investments is 1.8 (significant at the one percent level) when we do not control for interest rates or 1.5 percent (significant at the five percent level) when the impact of interest rates is controlled for.

To summarize, we have established that the euro affects investments positively for firms from the weakeuro countries. The channel that the euro operates is the indirect channel of increasing Qs. This indirect channel is especially strong for firms that were negatively affected by currency depreciations. This points to a conclusion that a decrease in cost of capital is the main reason for increased investments. For the firms from strong-euro countries, the direct effect of the euro dominates. The euro has decreased investments especially for small firms and for firms that were not exposed to currency risks. We next try to shed light 
on this phenomenon by studying the impact of financial constraints.

\section{Investments and financial constraints}

\subsection{Constrained vs. unconstrained firms}

So far we have shown that the effects for the weak-euro firms are consistent with the Q theory of investment since the effect of the euro is reflected in the market valuation of firms' investment opportunities -Tobin's Q - which indeed determines actual investment rates.

Our previous results also show a significant negative direct effect of the common currency on investments which is not captured by Q. As Hayashi (1982), Jorgenson (1971), and Fazzari et al. (1988) among others have shown, any determinant of investments that is not captured by $\mathrm{Q}$ is a reflection of some kind of market frictions typically resulting in firms being financially constrained. Since we have shown that the euro has a negative direct effect on some firms' investments, it is possible that the euro has limited some firms access to financial markets. However, it can be argued that the euro should improve firms' access to financing. Using the methodology developed by Rajan and Zingales (1998), Guiso et al. (2004) argue that financial integration in Europe will benefit most the countries that have the least developed financial markets. The reason is that the euro makes it easier firms from less developed countries to access more developed financial markets in other euro-countries. Also regulatory harmonization within the EU should lead to better functioning financial markets and thus to relaxation of financing constraints. In this section we analyze what is the role of financial constraints in determining firms' investments. If the euro has made it harder for some firms to access financial markets, then it is the financially constrained firms that should experience the largest negative impact. If the euro has improved firms' access to financial markets, the financially constrained firms should demonstrate the largest positive impact.

We compute a measure of financial constraints for all the firms in our sample using the methodology in 
Kaplan and Zingales $(1997)^{9}$. We construct a synthetic index of financial constraints based on firms' cash flows, dividends, cash balances and leverage as in Lamont et al. (2001), Rajan and Zingales (1998) and Baker et al. (2003) among others ${ }^{10}$. Although this index ("KZ-index") was developed using US firms, we think it is the best measure available that is ready to be used and has received recognition in the finance literature as a measure of financing constraints. We compute the index based on data from 1997 in order to ensure that firms were financially constrained just prior to the introduction of the euro (1998 can be seen as a transition year and is thus too late to use for the classification).

We next classify firms according to whether their KZ-index is above or below the median values of the KZ-index within their respective countries ${ }^{11}$ and estimate the investment regression. High KZ-index indicates that the firm is financially constrained. Results are in Table 7.

\section{[Insert Table 7: Constrained vs Unconstrained Firms: Investment and the Euro]}

To gauge the impact of financial constraints, we first measure the impact of financial constraints for non-euro firms. This effect is reflected in the coefficient of the variable "Constrained firm $\mathrm{x}$ post-euro dummy". The coefficient is negative and significantly different from zero at the one percent level, suggesting that constrained firms invest $3.9-4.0$ percent less than unconstrained firms in non-euro countries after 1998. Within weak-euro countries, we find that financially unconstrained firms enjoy a larger increase in Tobin's Q. The difference between financially constrained and financially unconstrained firms is significantly different at the 10 percent rate (regressions 1 and 3). Overall, the indirect increase in investments for

\footnotetext{
${ }^{9}$ We have also used payment of dividends as way of defining financing constraints, as in Fazzari et al. (1998). The results are very similar to the results we get using the methodology of Kaplan and Zingales. Thus the results are omitted.

${ }^{10}$ See Appendix D for details on how to compute the index of financial constraints.

${ }^{11}$ By classifying firms as constrained or unconstrained relative to other firms within each individual country, we control for cross-country differences in the index components that have nothing to do with financial constraints.
} 
financially unconstrained firms as a result of the common currency is 2.8 percent $(0.221 \times 0.128)$ and 1.58 percent for financially constrained firms. We also find evidence of direct increases in investments due to the euro. Investments have increased directly by 2.5 percent for financially constrained firms from the weak-euro countries after controlling for $\mathrm{Q}$ when we take the impact of interest rates into account

To summarize - we find in this section that among weak-euro firms, the euro has increased investments indirectly through an increase in Q. We also find some evidence that the euro has improved constrained firms' access to financial markets. The indirect effect is consistent with findings in Bris et al. (2003b). The effect of the euro on financial constraints is consistent with the arguments in Guiso et al. (2004).

The indirect results for firms in strong-euro countries are not statistically significant. We find, however, negative direct effect for unconstrained firms in strong-euro countries: unconstrained firms in strong-euro countries have investment rates which are 3 percent lower than for non-euro firms after 1998, controlling for the effect of $\mathrm{Q}$ on investment. There are some possible explanations for this finding. First of all, this result is not consistent with the explanation that the euro has made it harder for firms to access financial markets. If that claim were true then we should expect the financially constrained firms - firms that need external financing the most - to be affected the most. This is not the case.

It may be that the euro has made financially unconstrained firms constrained. We have tested this hypothesis by estimating an ordered probit model where the endogenous variable is the change in KZindex from the pre-euro period to the post-euro period (taking values of zero if the KZ-index changes within 0.5 standard deviations, and \pm 1 depending on whether it increases or decreases more than 0.5 standard deviations). Controlling for the level of the pre-euro KZ-index, changes in interest rates, as well as country- and firm-specific controls, we find that the pre-euro KZ-index is significantly and negatively related to changes in the KZ-index. This is not surprising since the most financially constrained firm in the sample can only stay the same or else become less constrained and the opposite. However, we do not find evidence that firms that were financially unconstrained become more constrained. 
An alternative explanation is that some firms in strong-euro countries are reorganizing and perhaps cutting capacity. If there is overcapacity then there is naturally no need to invest that much. For financially constrained firms there may be two opposing factors: the euro has made it easier to obtain financing, but due to reorganization there is not that much need for external financing. These two effects may cancel each other out. For financially constrained firms there is only the latter effect: firms do not want to invest that much and hence those firms experience a decline in investments.

\subsection{Financial constraints and bond markets}

Rajan and Zingales (2003), Pagano and Von Thadden (2004), and Detken and Hartmann (2002) emphasize the dramatic growth in bond issuance in the euro area after 1998. In particular, Detken and Hartmann (2002) report that the share of bond issues in euros as a percentage of total issuance activity in the world rises from 20 percent to 29 percent by early 2002. Rajan and Zingales (2003) provide panel data evidence that such increase is due to the euro. The euro may have opened access to the bond market to companies that were previously unable to do so and thus may have reduced their financial constraints, for instance, by reducing hold-up problems with banks. Therefore it is interesting to analyze whether bond issuance activity allows firms to invest more. This would imply a direct effect of the euro on investments through the removal of financial constraints.

We start by compiling a dataset of all debt issues by firms in Europe in the period 1995-2002 from the Securities Data Corporation. We obtain information on the identity of the issuer, principal amount, type of security, market of issuance and coupon and maturity characteristics. We classify debt issues into private debt and public bonds and aggregate the principal amount by company and year when a firm makes several issues with the same characteristics in a given year. There are initially 1,920 issues over the entire

period, corresponding to 1,106 single issuer-year observations. We then match the resulting panel with our balanced panel of firm-year observations, and we are left with 301 firm-year observations with some 
issuance activity. ${ }^{12}$

We now proceed to analyze the impact of bond issuance activity on firm investments. In Table 8 we implement our investment regressions using a public debt issue dummy as a determinant of Tobin's Q and investments. We do not find any significant effect of financing on Q but there is a significant impact of bond issuance activity on investments. Bond issuers invest 2.3 percent more than non-issuers. This result shows that access to public debt markets has a significant positive impact on investments. This result may indicate that some firms were financially constrained before and due to more developed bond markets after the introduction of the euro are able to invest more. Interestingly, even after controlling for bond issuance activity, financially unconstrained firms in strong-euro countries invest 2.7 percent less after 1998.

\section{[Insert Table 8: Bond Issuance, Financial Constraints Investment and the Euro]}

In Panel B we interact our measure of financial constraints with the bond issue dummy. Regarding the difference between financially unconstrained and financially constrained firms, we obtain similar results to those in Table 7. We then find that bond issuers in general increase investments by 3.5 percent after 1998. Constrained firms invest 3.8 percent less than similar firms and 9.8 percent less $(3.8+5.8)$ if they issue bonds. This is not due to the euro since it happens for all firms, irrespective of their euro membership.

We additionally find a significant effect of bond issuance activity for financially constrained firms in strong-euro countries: firms of this type that issue bonds increase investments by $2.8+5.7=8.5$ percent more relative to non-euro firms. In addition to the indirect valuation effect of 2.8 , bond issuers invest 5.7 percent more relative to non-euro firms because of a relaxation of their financial constraints. This provides some evidence in favor of Guiso et al. (2004). However, the effect of the euro on the financial constraints of bond issuers becomes insignificant once we control for changes in interest rates.

\footnotetext{
${ }^{12}$ Since we have 1,401 firms in our sample and the total available firms that exist at least one year is above 6,000, we lose roughly one out of four issuers. Therefore the sample of bond issues is still quite representative.
} 
Access to public bond markets increases significantly firms' investments after controlling for firm characteristics. Bond issuance also has a positive impact both directly and indirectly on constrained strong-euro firms' investments after 1998 although the direct effect is only significant in one of the specifications. Bond issuance activity does not have a positive indirect or direct effect on weak-euro firms' investments. Interestingly, the euro still has a negative direct effect on investments for firms that come from strong-euro countries and that are unconstrained. This result is consistent with the view that the investments have declined for those firms for reasons that are unrelated to financing. A plausible, consistent explanation is that these firms do not want to invest more because they are restructuring and cutting capacity.

\section{Robustness tests}

\subsection{Time effects}

The data we use in this paper consist primarily of end-of-year accounting information. Considering 1999 as the year of introduction of the euro implies that the data for 1999 reflects the real effects of the actual introduction of the common currency. However, already on May 2, 1998 the European Council decided on which countries were allowed to enter the final phase of the euro. Thus, choosing (the end of) 1998 as the first year of the euro seems also reasonable. Even this choice can be considered too conservative, given that forward looking markets are likely to have taken into account the effects of the introduction of the euro already at the end of 1997 , or even earlier.

In this section we perform robustness tests pertaining to the date of introduction of the euro as well as the time persistence of the effects we identify in the previous section. Table 9 reports the results. To isolate a possible temporary effect in 1998, we construct two time dummies, one that equals one in 1998 and afterwards, zero otherwise; and another one that takes value one in 1999 and afterwards, zero otherwise. We interact these time dummies with euro-country indicators and run our standard investment regressions. 
Table 19 shows that the main effect of the euro on investments does not happen before 1999.

\section{[Insert Table 9: Anticipation Effects]}

Ideally we would like to perform a long-run analysis of the effects of the euro but for obvious reasons our horizon does not extend more than five years after its introduction. Results in Table 9 show at least that the effects of the common currency on investments have not been temporary.

\subsection{Results by industry}

Our next robustness test analyzes whether the effects we identify in the previous sections are driven by firms in a particular industry. The existing evidence supports the view that the effects of the euro have been widespread across industries. Hardouvelis et al. (2004) study the impact of euro on the cost of equity capital. They find that the cost of equity has been reduced in Europe in all industries except for information technology and cyclical consumer goods. Bris et al. (2003b) find that the positive valuation effects of the euro are significant in all sectors, except for non-cyclical services with a similar methodology to ours.

\section{[Insert Table 10: Industry Effects]}

We classify firms in our sample into five industry groups: Manufacturing; Transportation, Communications and Utilities; Wholesale and Retail Trade; Services; and Basic Industries. This classification is based on SIC codes reported by Worldscope. We find significant effects for strong-euro countries in all non-manufacturing sectors. For those sectors investments have decreased after controlling for the investment opportunities. The direct euro effect on investments is -3.2 percent for Trade, -4.6 percent for Services, and -6.8 percent for Communications, Transportation, and Utilities. These results are consistent with the view that the non-tradable sector in strong-euro countries has previously overinvested and is now

restructuring and hence investing less. From the previous results we know that the negative direct euro 
effect on investments also holds for small companies and for companies that are not exposed to exchange rate risks. These companies are also more likely to be in non-manufacturing sector.

The other main result in this section is that our previous findings for the weak-euro countries are not driven by any particular industry since investments increase in all industries, and such effect is reflected by increases in Tobin's Q. Investment increases due to the indirect euro effect are 1.85 percent for Manufacturing, 1.12 percent for Trade, 4.45 percent for Services, 3.16 percent for Communications, Transportation, and Utilities; and 2.50 percent for Basic Industries.

\subsection{Are the results driven by a particular country?}

Table 1 shows that most of the firms in our sample of euro firms (374 out of 713 , or 52 percent) are either French or German, while most of the firms in the sample of non-euro firms ( 444 out of 688 , or 65 percent) are from the U.K. As a last robustness check, we replicate our regressions after excluding firms from France, Germany, and the U.K., from the sample. Results are in Table 11 Panel A.

\section{[Insert Table 11: Results Excluding the Big Countries]}

Excluding the three big countries reduces the number of observations by two thirds and leaves the effect of the euro insignificant, especially once we control for interest rates. One can argue that the lack of significance is driven by a reduced number of observations but this does not explain why the coefficients for weak-euro countries become insignificant with all the weak-euro countries still in the sample. Therefore we try the alternative of excluding only the U.K. in one specification and only France and Germany in another. The first alternative provides similar results to Table 11 Panel A and are therefore not reported in the paper. However, Panel B of Table 11 shows that removing France and Germany from the sample (both strong-euro countries) provides significant results that are consistent with the Q theory of investment. Without controlling for interest rates, Tobin's Q for strong-euro countries (other than France and Germany) increases by 7.7 percent which translates in an increase investments of 1 percent, relative to non-euro firms. 
This result is not significant after controlling for interest rates. Similarly, Tobin's Q for weak-euro countries increases 18.7 percent after 1998 which implies an investment rate 2.43 higher than non-euro firms. The result persists after using interest rates as instruments (although the effect on investment is now 1.4 percent).

We can therefore conclude that it is among French and German companies that the euro has had a negative impact on investments and that negative impact is unrelated to the market valuation of firms' investment opportunities.

\section{Conclusions}

The introduction of the euro in January 1999 has led to a whole body of literature devoted to analyzing the effects of the common currency on countries and firms. At the macroeconomic level, we have evidence regarding the effects of the euro on: trade, inflation, transmission of monetary shocks, yield spreads, fiscal policy harmonization, among others. ${ }^{13}$ At the corporate level, there are studies that analyze the impact on market risk (Bartram and Karolyi, 2003) and the cost of capital (Sentana, 2002; Hardouvelis et al. 2004; Bris et al., 2003b). This paper contributes to this growing literature by documenting a significant effect of the euro on the real economic activity at the corporate level. We show that the common currency has resulted in an increase in the investment rates which is consistent with the positive valuation effects reported in previous studies. In addition, we show that the euro has made it easier to access financing in Europe.

Our results show that the euro has benefitted companies in the euro-countries. This is true for all companies that come from countries that previously had weak currencies. In addition, the euro has had a positive effect on the investment rates for those firms coming from the strong-euro countries that have

\footnotetext{
${ }^{13}$ See EMU: Assessing the Impact of the Euro, special issue of Economic Policy, October 2003.
} 
had access to corporate bond markets. Thus our assessment of the euro is more positive than the received wisdom among European pundits who seem to think that the common currency has not resulted in any positive economic effects. To be fair, even our study finds that the euro has not been beneficial to most companies that hail from the strong-euro countries. Especially for France and Germany, the assessment at this point has to be negative.

Our approach can be seen as a reduced-form analysis on the relationship between investments and Q, in the presence of a shock to the cost of capital and to firms' financial constraints. There are papers which explicitly model such relationship in the presence of shocks (see Love, 2003). We build upon classic models of investments where anything different from a market friction affects investments only through an effect on Tobin's Q. Our simple approach yields easily interpretable results.

We deem our contribution important not only for academics interested in the effects of common currencies. The euro is by itself a natural experiment that represented a shock to firms in its area: because of an elimination of currency risks, firms face a lower cost of capital and better investment opportunities. Therefore, by measuring the impact of the euro on firms' investment, we contribute to the international finance literature by showing that elimination of currency risks do have major valuation effects that lead also to significant real effects. In addition, our results show that the introduction of the euro has fostered the development of European financial markets. This has led to improved access to financing and increased investments. Thus, improving investor protection or securities laws are not the only ways to achieve positive results on the development of financial markets.

Our paper calls for a natural extension. After looking at value and investment changes driven by the introduction of the euro, the next question is how these investments have been financed. As Stulz (1999) points out, a reduction in the cost of capital entails a reduction in the cost of equity as well as in the cost of debt. Therefore, it would be of great relevance to investigate whether financial integration and cost of 
capital reductions lead to a preference of equity over debt, or vice versa. ${ }^{14}$

${ }^{14}$ Our preliminary results in Bris, Koskinen, and Nilsson (2003a) suggest, that the investments have been financed with debt. 


\section{A Appendix: Variable definitions}

\begin{tabular}{|c|c|}
\hline Variable & Definition (item \# refers to Worldscope field) \\
\hline Investment rate $_{t}$ & $\begin{array}{l}\text { [Capital expenditures (item \#04601) + Net Assets from Acquisitions (item \#04355) } \\
+ \text { Additions to other assets (item \#04651) + R\&D expenses (item \#01201) }]_{\mathrm{t}} \div[\text { Total } \\
\text { assets (item } \# 02999)- \text { cash \& short term investments (item \#02001) }]_{\mathrm{t}-1} \text {. The values } \\
\text { of the components are expressed in domestic currency and adjusted for inflation } \\
\text { using the GDP-deflator. Thus, this variable captures real investments. }\end{array}$ \\
\hline Cash flow/assets $\mathrm{t}_{\mathrm{t}-1}$ & Funds from operations $\mathrm{t}_{\mathrm{t}-1}($ item $\# 04651) \div$ Total $^{\text {assets }} \mathrm{t}_{\mathrm{l}-1}($ item \#02999) \\
\hline Cash/assets $\mathrm{t}_{\mathrm{t}-1}$ & 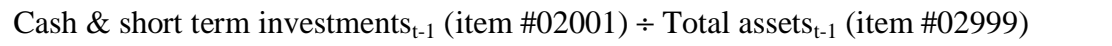 \\
\hline Leverage $_{\mathrm{t}-1}$ & Total debt $t_{\mathrm{t}-1}($ item $\# 03255) \div$ Total assets $_{\mathrm{t}-1}($ item \#02999) \\
\hline Sales $_{\mathrm{t}-1}$ & 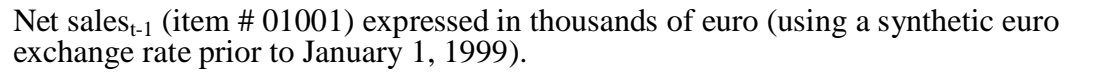 \\
\hline Firm $Q_{t-1}$ & $\begin{array}{l}\text { [Market value of common equity (item \# 08001) + Total assets (item \#02999)- Book } \\
\text { value of common equity (item \#03501) }]_{\mathrm{t}-1} \div \text { Total } \text { assets }_{\mathrm{t}-1}(\text { item \#02999) }\end{array}$ \\
\hline Industry $\mathrm{Q}_{\mathrm{t}-1}$ & $\begin{array}{l}\text { The median firm } \mathrm{Q}_{\mathrm{t}-1} \text { in each two-digit SIC code industry, calculated using all firms } \\
\text { from the sample countries with available data in Worldscope on } \mathrm{Q}_{\mathrm{t}-1} \text { (irrespective of } \\
\text { whether the firms are included in the regression sample). }\end{array}$ \\
\hline GDP growth $_{\mathrm{t}-1}$ & The real growth rate in GDP in year $t-1$. \\
\hline GDP/capita $\mathrm{t}-1$ & Real GDP per capita in year $t-1$, expressed in euros. \\
\hline $\begin{array}{l}\text { Relative change in domestic/USD } \\
\text { exchange rate } \text { t- }^{1}\end{array}$ & $\begin{array}{l}\left.\text { [Domestic currency/USD exchange rate }{ }_{t} \text { - domestic currency/USD exchange rate } \mathrm{t}_{\mathrm{t}-1}\right] \\
\div \text { domestic currency/USD exchange rate } \mathrm{t}_{\mathrm{t}-1}\end{array}$ \\
\hline Absolute change in $\log (\text { firm } \mathrm{Q})_{\mathrm{t}-1}$ & The absolute value of $\left[\log (\text { firm } Q)_{t-1}-\log (\text { firm } Q)_{t-2}\right]$ \\
\hline Absolute change in $\log (\text { industry } \mathrm{Q})_{\mathrm{t}-1}$ & The absolute value of $\left[\log (\text { industry } Q)_{t-1}-\log (\text { firm } Q)_{t-2}\right]$ \\
\hline Short-term interest rate $\mathrm{t}_{\mathrm{t}-1}$ & 6 month treasury bill yield in year $t-1$ \\
\hline Term spread $_{\mathrm{t}-1}$ & $\begin{array}{l}\text { Difference in yields between } 10 \text { year government bond and } 6 \text { month treasury bill in } \\
\text { year } t \text { - } 1 \text {. }\end{array}$ \\
\hline Change in short-term interest rate ${ }_{t}$ & Short-term interest rate t $_{\mathrm{t}}$ Short-term interest rate $\mathrm{t}_{\mathrm{t}-1}$ \\
\hline Change in term spread $_{t}$ & Term-spread ${ }_{t}-$ Term-spread $_{t-1}$ \\
\hline
\end{tabular}




\section{B Appendix: Average corporate investment rates by country before}

\section{and after the introduction of the euro}

The sample is a balanced panel of 1401 firms from the Euro-countries (except Greece) and five Non-euro countries (Denmark, Norway, Sweden, Switzerland, and UK) with complete data in Worldscope over the time period 1995-2002. The table displays the average corporate investment rate for the pre-euro time period (1995-1998) and the post-euro time-period (1999-2002), respectively. The each firm's investment rate in year $t$ is calculated as total corporate investments during the year (Worldscope item \#04355 + item \#04601 + item \#04651 + item \#01201) divided by beginning-of-period book value of non-cash assets (item \#02999 - item \#02001). The euro-countries classified as weak (i.e., countries with a recent currency crisis) are: Finland, Italy, Ireland, Portugal and Spain. The corporate investment rate is winsorized at the $99^{\text {th }}$ percentile value of the total sample to reduce the influence of outliers. For the reported t-tests, $*$ and $* *$, indicates significance at the $5 \%$, and $1 \%$-levels, respectively.

\begin{tabular}{lcccc}
\hline & \multicolumn{3}{c}{ Average corporate investment rate } \\
\cline { 2 - 5 } & $\begin{array}{c}\text { Number of } \\
\text { firms }\end{array}$ & $\begin{array}{c}\text { Pre-euro time } \\
\text { period }\end{array}$ & $\begin{array}{c}\text { Post-euro time } \\
\text { period }\end{array}$ & $\begin{array}{c}\text { Difference } \\
\text { (Post-euro -Pre-euro) }\end{array}$ \\
\hline Euro countries: & & & & \\
Austria & 28 & 0.128 & 0.091 & -0.037 \\
Belgium & 39 & 0.144 & 0.106 & -0.038 \\
Finland & 42 & 0.172 & 0.131 & -0.041 \\
France & 175 & 0.112 & 0.084 & -0.028 \\
Germany & 199 & 0.162 & 0.109 & -0.053 \\
Ireland & 17 & 0.196 & 0.137 & -0.059 \\
Italy & 60 & 0.103 & 0.089 & -0.014 \\
Luxemburg & 3 & 0.127 & 0.086 & -0.041 \\
Netherlands & 73 & 0.217 & 0.159 & -0.058 \\
Portugal & 20 & 0.106 & 0.079 & -0.027 \\
Spain & 57 & 0.088 & 0.081 & -0.007 \\
& & & & \\
Non-euro countries: & & & & -0.011 \\
Denmark & 64 & 0.145 & 0.134 & -0.134 \\
Norway & 39 & 0.249 & 0.115 & -0.059 \\
Sweden & 56 & 0.172 & 0.113 & -0.015 \\
Switzerland & 85 & 0.118 & 0.103 & -0.053 \\
United Kingdom & 444 & 0.182 & 0.128 & \\
\hline
\end{tabular}

\section{Appendix: Calculation of exchange rate exposures}

We measure exchange rate exposure by calculating the sensitivity of stock prices to fluctuations in the domestic currency. A commonly used method of calculating a firm's exposure to currency risk is to estimate the following regression:

$$
R_{i j t}=\alpha_{i}+\varpi_{i} R_{m t}^{j}+\beta_{i}^{x} R_{x t}^{j}++u_{i j t}
$$

where $R_{i j}$ is the stock return of firm $i$ in country $j, R_{m}^{j}$ is the monthly return on the domestic market portfolio in country $j, R_{x}^{j}$ is the monthly change in the exchange rate in country $j$, and the $\beta_{i}^{x}$ 's are then measures of currency exposure. Such an approach is used by Jorion (1990), Bodnar and Gentry (1993), 
and Amihud (1994). ${ }^{15}$ We use a similar procedure where we regress individual stock returns on market returns, and changes in exchange rates. The coefficient $\beta_{i}^{x}$ measures the direct effect of exchange rates on firm returns, and is henceforth refer to as exchange rate beta (ERB). We estimate the model in (3) using monthly data from January 1992 through December $1994 .{ }^{16}$ We deliberately choose an estimation period that is before our sample period, in order to avoid potential endogeneity problems. Stock price data are from Datastream.

We calculate exchange rate betas (ERBs) with respect to the euro. Although the euro existed only after January 1, 1999, Datastream computes a synthetic euro rate based on the weights each currency has in the real euro. The exchange rates are expressed as units of domestic currency per euro. Because some firms lack stock return data before 1995, the ERB sample is smaller than our original sample. Because we define exchange rates as units of domestic currency per euro, a firm with a positive ERB is most likely an exporting firm. Similarly, a firm with a negative ERB is most likely an importing firm, a firm with foreign-denominated liabilities, or both.

We classify firms into three groups depending on the sign and significance of $\beta_{i}^{x}$ :

-Negative ERB firms, for which $\beta_{i}^{x}<0$, and the coefficient in regression (3) is significant at the five percent level of better. Firms with negative ERBs have stock returns that decrease when the domestic currency depreciates with respect to the euro.

-Positive ERB firms, for which $\beta_{i}^{x}>0$, and the coefficient in regression (3) is significant at the five percent level of better. Firms with positive ERBs have stock returns that increase when the domestic currency depreciates with respect to the euro.

\footnotetext{
${ }^{15}$ Jorion (1991) uses a version of this two-factor model, in which the return of the market portfolio is the first factor and the component of innovations in the exchange rate that is orthogonal to the market return is the second factor. However the procedure affects only the estimates of the market beta, not the exchange rate exposures.

${ }^{16}$ If there are fewer than 18 observations available per firm, we exclude it from the estimation.
} 
-The rest of firms, for which the exposure coefficient is not statistically significant.

Relative to a measure of currency risk based on accounting variables (foreign sales, imports, foreign debt, exports to sales) our measure incorporates the effect of hedging on a firm's exposure. Moreover, it takes into account the joint effect of a firm's decisions with respect to foreign markets, whose interaction is hard to identify in accounting-based exposure measures. However, ERBs assume that currency exposure has not changed after 1994.

\section{Appendix: Measuring financial constraints}

We compute a measure of financial constraints for all the firms in our sample using the methodology in Kaplan and Zingales (1997). They estimate an ordered logit regression using a sample of 49 manufacturing firms. One can construct a synthetic index of financial constraints using the coefficients in their estimation. The index we compute is:

$$
K Z_{i t}=-1.002 \times \frac{C F_{i t}}{A_{i t}}-39.368 \times \frac{D I V_{i t}}{A_{i t}}-1.315 \times \frac{C_{i t}}{A_{i t}}+0.283 \times Q_{i t}+3.139 \times \text { Leverage }_{i t}
$$

where $C F_{i t} / A_{i t}$ is cash flow over assets, $D I V_{i t} / A_{i t}$ is cash dividends over assets, $C_{i t} / A_{i t}$ is cash balances over assets, $Q_{i t}$ is the firm's Q ratio, and Leverage $i t$ is the total debt-to-assets ratio. Detailed definitions of the variables are in the Appendix A. A larger value of the index indicates a more financially constrained firm. We compute the index based on data from 1997, in order to ensure that firms were financially constrained just prior to the introduction of the euro (1998 can be seen as a transition year, and is thus too late to use for the classification). 


\section{References}

Amihud, Y., 1994. Exchange Rates and the Valuation of Equity Shares. In Y. Amihud, Y., Levich, R.M. (eds.), Exchange Rates and Corporate Performance. Irwin, New York, pp. 49-59.

Barr, D., Breedon, F., Miles, D., 2003. Life on the Outside: Economic Conditions and Prospects Outside Euroland. Economic Policy 18, 573-613.

Bartram, S., Karolyi, G.A., 2003. The Impact of the Introduction of the Euro on Foreign Exchange Risk Exposures. Unpublished working paper. Ohio State University.

Bertrand, M., Duflo, E., Mullainathan, S., 2004. How Much Should We Trust Differences-in-Differences Estimates?. Quarterly Journal of Economics 119, 249-75.

Bodnar, G.M., Gentry, W., 1993. Exchange Rate Exposure and Industry Characteristics: Evidence from Canada, Japan, and the U.S. Journal of International Money and Finance 12, 29-45.

Blanchard, O., López de Silanes, F., Shleifer, A., 1994. What Do Firms Do with Cash Windfalls?. Journal of Financial Economics 36, 337-60.

Bris, A., Koskinen, Y., Nilsson, M., 2003a. The Euro Is Good After All: Corporate Evidence. SSE/EFI working paper no. 510 .

Bris, A., Koskinen, Y., Nilsson, M., 2003b. The Euro and Corporate Valuations. SSE/EFI working paper no. 525 .

Bun, M.J.G., Klaassen, F.J.G.M., 2002. Has the Euro Increased Trade?. Unpublished working paper.

Dahlquist, M, Robertsson, G., 2001. Direct Foreign Ownership, Institutional Investors, and Firm Characteristics. Journal of Financial Economics 59, 413-40. 
Detken, C, Hartmann, P., 2002. Features of the Euro's Role on International Financial Markets. Economic Policy, Fall 2002.

Erickson, T., Whited, T.M., 2000. Measurement Error and the Relationship between Investment and Q. Journal of Political Economy 108, 1027-57.

Fazzari, S.,Hubbard, R.G., Petersen, B., 1988. Financing Constraints and Corporate Investment. Brookings Papers on Economic Activity, 141-95.

Frankel, J., Rose, A., 2002. An Estimate of the Effect of Common Currencies on Trade and Income. Quarterly Journal of Economics 117, 437-66.

Friberg, R., 2001. Two Monies, Two Markets? Variability and the Option to Segment. Journal of International Economics 55, 317-27.

Gertler, M, Hubbard, R.G., 1988. Financial Factors in Business Fluctuations. In Financial Market Volatility, Federal Reserve Bank of Kansas City, Kansas City, Mo.

Glick, R., Rose. A., 2002. Does a Currency Union Affect Trade? The Time-Series Evidence. European Economic Review 46, 1125-51.

Guiso, L., Japelli, T., Padula, M., Pagano, M., 2004. Financial Market Integration and Economic Growth in the EU. Economic Policy, forthcoming.

Hall, R.E., Jorgenson, D.W., 1967. Tax Policy and Investment Behavior. American Economic Review $57,391-414$.

Hardouvelis, G.A., Malliaropoulos, D., Priestley, R., 2004. The Impact of Globalization on the Equity Cost of Capital. CEPR discussion paper no. 4346. 
Hayashi, F., 1982. Tobin's Marginal Q and Average Q: A Neoclassical Interpretation. Econometrica 50, 213-24.

Hayashi, F., Inoue, T., 1991. The Relation between Firm Growth and Q with Multiple Capital Goods: Theory and Evidence from Panel Data on Japanese Firms. Econometrica 59, 731-53.

Hoshi, T., Kashyap, A.K., Scharfstein, D., 1991. Corporate Structure, Liquidity, and Investments: Evidence from Japanese Industrial Groups. Quarterly Journal of Economics 56, 33-60.

Jorgenson, D.W.,1963. Capital Theory and Investment Behavior. American Economic Review 53, 247-59.

Jorgenson, D.W., 1971. Econometric Studies of Investment Behavior: A Survey. Journal of Economic Literature 9, 1111-47.

Jorion, P., 1990. The Exchange Rate Exposure of U.S. Multinationals. Journal of Business 63, 331-45.

Kaplan, S.N., Zingales, L., 1997. Do Investment-Cash Flow Sensitivities Provide Useful Measures of Financing Constraints?. Quarterly Journal of Economics 112, 169-216.

Kashyap, A.K., Lamont, O.A., Stein, J.C., 1994. Credit Conditions and the Cyclical Behavior of Inventories. Quarterly Journal of Economics 109, 565-592.

Lamont, O.A., 1994. Cash Flow and Investment: Evidence from Internal Capital Markets. Journal of Finance 52, 83-109.

Love, I., 2003. Financial Development and Financial Constraints: International Evidence from the Structural Investment Model. Review of Financial Studies 16, 765-91.

Micco, A., Stein, E., Ordóñez, G., 2003. The Currency Union Effect on Trade: Early Evidence from EMU. Economic Policy 18, 315-356. 
Myers, S., Majluf, M., 1984. Corporate Financing and Investment Decisions when Firms Have Information that Investors Do Not Have. Journal of Financial Economics 13, 187-221.

Pagano, M., von Thadden, E-L., 2004. The European Bond Markets under EMU. Oxford Review of Economic Policy, forthcoming.

Rajan, R.G., Zingales, L., 1998. Financial Dependence and Growth. American Economic Review 88, $559-587$.

Rajan, R.G., Zingales, L., 2003. Banks and Markets: The Changing Character of European Finance. In Gaspar, V., Hartmann, P., Sleijpen, O. (eds.), The Transformation of the European Financial System: Second ECB Central Banking Conference. Frankfurt am Main: European Central Bank.

Rose, A., 2000. One Money, One Market: Estimating the Effect of Common Currencies on Trade. Economic Policy 15, 9-48.

Rose, A., van Wincoop, E., 2001. National Money as a Barrier to Trade: The Real Case for Monetary Union. American Economic Review 91, 386-390.

Sentana, E., 2002. Did the EMS Reduce the Cost of Capital?. Economic Journal 112, 786-809.

Stulz, R., 1999. Globalization of Capital Markets and the Cost of Capital. Journal of Applied Corporate Finance, Fall , 8-25.

Tobin, J., 1969. A General Equilibrium Approach to Monetary Theory. Journal of Money, Credit, and Banking, 1, 15-29.

Whited, T.M., 1992. Debt, Liquidity Constraints, and Corporate Investment: Evidence from Panel Data. Journal of Finance 47, 1425-1470. 
Table 1. Sample characteristics

The sample is a balanced panel of 1401 firms from the Euro-countries (except Greece) and five Non-euro countries (Denmark, Norway, Sweden, Switzerland, and UK) with complete data in Worldscope over the time period 1995-2002. See Appendix A for variable definitions.

\begin{tabular}{|c|c|c|c|c|c|c|c|c|c|c|c|c|c|c|c|c|}
\hline \multirow[b]{2}{*}{ Country } & \multirow[b]{2}{*}{ \# firms } & \multirow{2}{*}{$\begin{array}{c}\text { \# firm-year } \\
\text { observations }\end{array}$} & \multicolumn{2}{|c|}{$\begin{array}{c}\text { Sales }_{\mathrm{t}-1} \\
\text { (in million euro) } \\
\end{array}$} & \multicolumn{2}{|c|}{ Firm $\mathrm{Q}_{\mathrm{t}-1}$} & \multicolumn{2}{|c|}{$\begin{array}{l}\text { Pre-euro fraction } \\
\text { international sales } \\
(\% \text { in 1997) }\end{array}$} & \multicolumn{2}{|c|}{$\begin{array}{c}\text { Euro exchange rate } \\
\text { beta } \\
\text { (estimated 1992-94) }\end{array}$} & \multicolumn{2}{|c|}{$\begin{array}{l}\text { Short-term } \\
\text { interest rate }{ }_{\mathrm{t}-1} \\
(\%)\end{array}$} & \multicolumn{2}{|c|}{$\begin{array}{c}\text { Term-spread } \\
(\%)\end{array}$} & \multicolumn{2}{|c|}{$\begin{array}{c}\text { GDP-growth } \\
(\%)\end{array}$} \\
\hline & & & Mean & Std. dev. & Mean & Std. dev & Mean & Std. dev. & Mean & Std. dev. & Mean & Std. dev. & Mean & Std. dev. & Mean & Std. dev. \\
\hline Austria & 28 & 224 & 739.3 & $1,240.9$ & 1.122 & 0.287 & 11.0 & 11.1 & -0.292 & 1.287 & 4.0 & 0.7 & 1.8 & 0.7 & 2.3 & 1.0 \\
\hline Belgium & 39 & 312 & $1,378.1$ & $2,980.5$ & 1.417 & 0.706 & 12.5 & 13.8 & -0.002 & 0.907 & 4.0 & 0.9 & 1.9 & 0.8 & 2.5 & 1.2 \\
\hline Finland & 42 & 336 & $1,540.9$ & $3,620.6$ & 1.455 & 1.281 & 15.2 & 14.3 & -0.071 & 0.886 & 4.1 & 1.0 & 2.2 & 1.1 & 4.1 & 1.5 \\
\hline France & 175 & 1,400 & $3,707.5$ & $9,668.4$ & 1.364 & 0.805 & 9.8 & 9.7 & 0.081 & 2.054 & 4.4 & 1.2 & 1.4 & 0.6 & 2.5 & 1.1 \\
\hline Germany & 199 & 1,592 & $2,668.9$ & $8,149.8$ & 1.446 & 0.875 & 13.5 & 13.7 & 0.108 & 1.354 & 4.0 & 0.8 & 1.6 & 0.8 & 1.7 & 0.7 \\
\hline Ireland & 17 & 136 & 863.0 & $1,678.2$ & 1.464 & 0.712 & 16.6 & 15.5 & -0.522 & 1.058 & 5.1 & 1.1 & 1.1 & 1.0 & 8.9 & 2.1 \\
\hline Italy & 60 & 480 & $3,759.8$ & $9,966.5$ & 1.211 & 0.568 & 9.6 & 11.3 & -0.623 & 1.224 & 6.4 & 2.7 & 1.0 & 0.8 & 2.1 & 0.7 \\
\hline Luxemburg & 3 & 24 & 939.9 & $1,317.2$ & 1.418 & 0.354 & 10.6 & 7.9 & $\mathrm{n} / \mathrm{a}$ & $\mathrm{n} / \mathrm{a}$ & 4.0 & 0.9 & 1.7 & 0.8 & 5.2 & 3.2 \\
\hline Netherlands & 73 & 584 & $3,871.1$ & $11,500.0$ & 1.648 & 1.043 & 18.8 & 18.8 & 1.060 & 1.324 & 3.9 & 0.8 & 1.8 & 0.8 & 3.2 & 1.0 \\
\hline Portugal & 20 & 160 & $2,088.7$ & $5,044.7$ & 1.367 & 0.595 & 8.4 & 9.2 & 0.681 & 1.298 & 6.2 & 2.9 & 0.9 & 0.8 & 3.3 & 0.9 \\
\hline Spain & 57 & 456 & 690.3 & $1,213.1$ & 1.130 & 0.345 & 9.2 & 11.2 & -0.401 & 1.767 & 5.8 & 2.2 & 1.3 & 0.5 & 3.4 & 0.9 \\
\hline All euro countries & 713 & 5,704 & $2,773.7$ & $8,238.9$ & 1.398 & 0.835 & 12.3 & 13.2 & 0.071 & 1.592 & 4.7 & 1.8 & 1.2 & 1.2 & 3.6 & 2.4 \\
\hline Denmark & 64 & 512 & 540.6 & 870.8 & 1.645 & 2.245 & 14.0 & 14.6 & 0.488 & 1.671 & 4.6 & 1.1 & 1.7 & 1.0 & 2.9 & 1.1 \\
\hline Norway & 39 & 312 & $1,003.4$ & $2,686.2$ & 1.497 & 0.943 & 18.2 & 18.2 & 0.042 & 2.961 & 5.8 & 1.1 & 0.6 & 1.4 & 3.7 & 1.5 \\
\hline Sweden & 56 & 448 & $2,043.8$ & $4,384.1$ & 1.597 & 1.415 & 14.2 & 15.3 & -0.323 & 2.003 & 5.2 & 2.0 & 1.7 & 0.6 & 3.2 & 1.4 \\
\hline Switzerland & 85 & 680 & $1,765.6$ & $5,747.4$ & 1.382 & 0.870 & 11.0 & 10.1 & -0.003 & 0.944 & 2.5 & 1.0 & 1.4 & 0.6 & 1.4 & 1.0 \\
\hline United Kingdom & 444 & 3,552 & $1,859.8$ & $7,351.8$ & 1.701 & 1.196 & 15.5 & 16.8 & -0.627 & 0.948 & 6.1 & 0.8 & 0.4 & 1.5 & 3.1 & 0.7 \\
\hline All non-euro countries & 688 & 5,504 & $1,691.9$ & $6,416.5$ & 1.636 & 1.307 & 14.9 & 16.0 & -0.383 & 1.376 & 4.8 & 1.8 & 1.5 & 0.9 & 2.9 & 1.4 \\
\hline All countries & 1,401 & 11,208 & $2,242.4$ & $7,419.6$ & 1.515 & 1.099 & 13.6 & 14.7 & -0.154 & 1.505 & 4.8 & 1.8 & 1.4 & 1.0 & 3.3 & 2.1 \\
\hline
\end{tabular}


Table 2. Average corporate investment rates before and after the introduction of the euro: Euro countries vs. non-euro countries

The sample is a balanced panel of 1401 firms from the Euro-countries (except Greece) and five Non-euro countries (Denmark, Norway, Sweden, Switzerland, and UK) with complete data in Worldscope over the time period 1995-2002. The table displays the average corporate investment rate for the pre-euro time period (1995-1998) and the post-euro time-period (1999-2002), respectively. The each firm's investment rate in year $t$ is calculated as total corporate investments during the year (Worldscope item \#04355 + item \#04601 + item \#04651 + item \#01201) divided by beginning-of-period book value of non-cash assets (item \#02999 - item \#02001). The euro-countries classified as weak (i.e., countries with a recent currency crisis) are: Finland, Italy, Ireland, Portugal and Spain. The corporate investment rate is winsorized at the $99^{\text {th }}$ percentile value of the total sample to reduce the influence of outliers. For the reported t-tests, * and ${ }^{* *}$, indicates significance at the 5\%, and $1 \%$-levels, respectively.

\begin{tabular}{lcccc|c}
\hline & \multicolumn{3}{c}{ Average corporate investment rate } \\
\cline { 2 - 6 } & $\begin{array}{c}\text { Number of } \\
\text { firms }\end{array}$ & $\begin{array}{c}\text { Pre-euro time } \\
\text { period }\end{array}$ & $\begin{array}{c}\text { Post-euro time } \\
\text { period }\end{array}$ & $\begin{array}{c}\text { Difference } \\
\text { (Post-euro -Pre-euro) }\end{array}$ & $\begin{array}{c}\text { T-test of } \\
\text { difference }\end{array}$ \\
\hline Euro countries & 713 & 0.142 & 0.104 & -0.038 & $11.80^{* *}$ \\
$\quad$ Strong euro countries & 517 & 0.149 & 0.106 & -0.043 & $11.69^{* *}$ \\
Weak euro countries & 196 & 0.122 & 0.099 & -0.023 & $3.70^{* *}$ \\
Non-euro countries: & 688 & 0.173 & 0.124 & -0.050 & $10.99^{* *}$ \\
\hline T-test of difference: & & & & & \\
Euro vs. non-euro countries & & $4.84^{* *}$ & $4.28^{* *}$ & $2.21^{*}$ & \\
$\quad$ Strong-euro vs. non-euro countries & & $3.38^{* *}$ & $3.53^{* *}$ & 1.12 & \\
Weak euro vs. non-euro countries & & $5.92^{* *}$ & $4.00^{* *}$ & $3.57^{* *}$ & \\
Strong- vs. weak-euro countries & & $3.20^{* *}$ & 1.18 & $2.88^{* *}$ & \\
\hline
\end{tabular}


Table 3. The introduction of the euro and corporate investments: OLS and 2SLS regression analysis

The sample is a balanced panel of 1401 firms from the Euro-countries (except Greece) and five Non-euro countries (Denmark, Norway, Sweden, Switzerland, and UK) with complete data in Worldscope over the time period 1995-2002. Estimation by 2SLS. The post-euro time period is defined as the years 1999-2002. See Appendix A for other variable definitions. Standard errors are reported within brackets. $*$ and $* *$, indicates significance at the $5 \%$, and $1 \%$-levels, respectively. The Sargan-test of overidentifying restrictions is a test of the validity of the instruments under the null that the instruments are valid.

\begin{tabular}{|c|c|c|c|c|}
\hline \multirow[b]{4}{*}{ Explanatory variable: } & \multicolumn{4}{|c|}{ 2SLS regressions } \\
\hline & \multicolumn{4}{|c|}{ Dependent variable: } \\
\hline & $\frac{\text { First stage }}{\log (\text { firm } Q)_{t-1}}$ & $\begin{array}{l}\text { Second stage } \\
\text { Investment rate }\end{array}$ & $\frac{\text { First stage }}{\log (\text { firm } Q)_{t-1}}$ & $\begin{array}{l}\text { Second stage } \\
\text { Investment rate }_{t}\end{array}$ \\
\hline & $(1)$ & $(2)$ & (3) & $(4)$ \\
\hline Euro country x post-euro dummy & $\begin{array}{l}0.099^{*} \\
{[0.050]}\end{array}$ & $\begin{array}{r}-0.012^{*} \\
{[0.006]}\end{array}$ & $\begin{array}{c}0.078 \\
{[0.046]}\end{array}$ & $\begin{array}{l}-0.010 \\
{[0.006]}\end{array}$ \\
\hline $\log (\text { firm Q) })_{t-1}$ (instrumented) & & $\begin{array}{c}0.128 * * \\
{[0.035]}\end{array}$ & & $\begin{array}{c}0.154 * * \\
{[0.033]}\end{array}$ \\
\hline Cash flow/assets $\mathrm{t}_{\mathrm{t}-1}$ & $\begin{array}{c}0.366^{* *} \\
{[0.111]}\end{array}$ & $\begin{array}{c}0.131 * * \\
{[0.021]}\end{array}$ & $\begin{array}{c}0.370 * * \\
{[0.108]}\end{array}$ & $\begin{array}{l}0.122 * * \\
{[0.020]}\end{array}$ \\
\hline Cash/assets $\mathrm{t}_{\mathrm{t}-1}$ & $\begin{array}{l}0.295 * * \\
{[0.074]}\end{array}$ & $\begin{array}{c}0.228 * * \\
{[0.021]}\end{array}$ & $\begin{array}{l}0.302 * * \\
{[0.073]}\end{array}$ & $\begin{array}{l}0.219 * * \\
{[0.021]}\end{array}$ \\
\hline Leverage $_{t-1}$ & $\begin{array}{l}-0.069 \\
{[0.053]}\end{array}$ & $\begin{array}{c}-0.120 * * \\
{[0.015]}\end{array}$ & $\begin{array}{l}-0.066 \\
{[0.053]}\end{array}$ & $\begin{array}{c}-0.118 * * \\
{[0.015]}\end{array}$ \\
\hline $\log (\text { sales })_{\mathrm{t}-1}$ & $\begin{array}{c}0.005 \\
{[0.017]}\end{array}$ & $\begin{array}{c}-0.028 * * \\
{[0.003]}\end{array}$ & $\begin{array}{c}0.007 \\
{[0.017]}\end{array}$ & $\begin{array}{c}-0.028 * * \\
{[0.003]}\end{array}$ \\
\hline GDP growth $_{t-1}$ & $\begin{array}{l}3.131 * * \\
{[1.170]}\end{array}$ & $\begin{array}{c}0.228 \\
{[0.203]}\end{array}$ & $\begin{array}{l}3.231 * * \\
{[1.073]}\end{array}$ & $\begin{array}{c}0.158 \\
{[0.203]}\end{array}$ \\
\hline $\log (\mathrm{GDP} / \text { capita })_{\mathrm{t}-1}$ & $\begin{array}{l}-0.368 \\
{[0.388]}\end{array}$ & $\begin{array}{c}0.074 \\
{[0.054]}\end{array}$ & $\begin{array}{l}-0.459 \\
{[0.257]}\end{array}$ & $\begin{array}{c}0.074 \\
{[0.054]}\end{array}$ \\
\hline $\begin{array}{l}\text { Relative change in domestic/USD } \\
\text { exchange rate } \text { ex-1 }_{\text {and }}\end{array}$ & $\begin{array}{c}-0.233^{*} \\
{[0.109]}\end{array}$ & $\begin{array}{c}0.075 * * \\
{[0.025]}\end{array}$ & $\begin{array}{c}-0.287 * * \\
{[0.100]}\end{array}$ & $\begin{array}{c}0.082 * * \\
{[0.025]}\end{array}$ \\
\hline $\begin{array}{l}\text { Absolute change in } \log (\text { firm } Q)_{t-1} \\
\text { (instrument) }\end{array}$ & $\begin{array}{l}0.204 * * \\
{[0.040]}\end{array}$ & & $\begin{array}{l}0.205^{* *} \\
{[0.039]}\end{array}$ & \\
\hline $\begin{array}{l}\text { Absolute change in } \log (\text { industry } \mathrm{Q})_{\mathrm{t}-1} \\
\text { (instrument) }\end{array}$ & $\begin{array}{l}-0.041 \\
{[0.025]}\end{array}$ & & $\begin{array}{l}-0.038 \\
{[0.024]}\end{array}$ & \\
\hline Change in short-term interest rate $_{t}$ & & & $\begin{array}{l}2.640^{*} \\
{[1.280]}\end{array}$ & $\begin{array}{l}-0.477 \\
{[0.318]}\end{array}$ \\
\hline Change in term-spread ${ }_{t}$ & & & $\begin{array}{c}0.063 \\
{[2.026]}\end{array}$ & $\begin{array}{l}-0.108 \\
{[0.376]}\end{array}$ \\
\hline $\begin{array}{l}\text { Short-term interest } \text { rate }_{\mathrm{t}-1} \\
\text { (instrument) }\end{array}$ & & & $\begin{array}{l}-2.524 \\
{[1.393]}\end{array}$ & \\
\hline $\begin{array}{l}\text { Term-spread } \\
\text { (instrument) }\end{array}$ & & & $\begin{array}{l}-3.050 \\
{[2.566]}\end{array}$ & \\
\hline Year dummies and fixed firm-effects & YES & YES & YES & YES \\
\hline Adjusted $\mathrm{R}^{2}$ excluding fixed firm effects & 0.137 & 0.147 & 0.144 & 0.139 \\
\hline Number of observations & 11,208 & 11,208 & 11,208 & 11,208 \\
\hline P-value from Sargan-test & & 0.438 & & 0.246 \\
\hline
\end{tabular}


Table 4. The introduction of the euro and corporate investments: Strong vs. weak euro countries

The sample is a balanced panel of 1401 firms from the Euro-countries (except Greece) and five Non-euro countries (Denmark, Norway, Sweden, Switzerland, and UK) with complete data in Worldscope over the time period 1995-2002. Estimation by 2SLS. The euro-countries classified as weak (i.e., countries with a recent currency crisis) are: Finland, Italy, Ireland, Portugal and Spain. The post-euro time period is defined as the years 1999-2002. See Appendix A for other variable definitions. Standard errors are reported within brackets. $*$ and $* *$, indicates significance at the $5 \%$, and $1 \%$-levels, respectively. The Sargan-test of overidentifying restrictions is a test of the validity of the instruments under the null that the instruments are valid.

\begin{tabular}{|c|c|c|c|c|}
\hline \multirow[b]{4}{*}{ Explanatory variable: } & \multicolumn{4}{|c|}{ 2SLS regressions } \\
\hline & \multicolumn{4}{|c|}{ Dependent variable: } \\
\hline & $\frac{\text { First stage }}{\log (\text { firm } Q)_{t-1}}$ & $\begin{array}{l}\text { Second stage } \\
\text { Investment rate }_{\mathrm{t}}\end{array}$ & $\frac{\text { First stage }}{\log (\text { firm } Q)_{t-1}}$ & $\begin{array}{l}\text { Second stage } \\
\text { Investment rate }_{\mathrm{t}}\end{array}$ \\
\hline & $(1)$ & $(2)$ & $(3)$ & $(4)$ \\
\hline Strong euro country $\mathrm{x}$ post-euro dummy & $\begin{array}{c}0.068 \\
{[0.045]}\end{array}$ & $\begin{array}{c}-0.017 * * \\
{[0.005]}\end{array}$ & $\begin{array}{c}0.058 \\
{[0.051]}\end{array}$ & $\begin{array}{l}-0.014 * \\
{[0.006]}\end{array}$ \\
\hline Weak euro country $\mathrm{x}$ post-euro dummy & $\begin{array}{c}0.173 * * \\
{[0.046]}\end{array}$ & $\begin{array}{c}0.001 \\
{[0.009]}\end{array}$ & $\begin{array}{l}0.131 * * \\
{[0.045]}\end{array}$ & $\begin{array}{c}0.007 \\
{[0.009]}\end{array}$ \\
\hline $\log (\text { firm } Q)_{\mathrm{t}-1}($ instrumented $)$ & & $\begin{array}{c}0.126 * * \\
{[0.036]}\end{array}$ & & $\begin{array}{l}0.131 * * \\
{[0.035]}\end{array}$ \\
\hline Cash flow/assets $_{\mathrm{t}-1}$ & $\begin{array}{c}0.369 * * \\
{[0.111]}\end{array}$ & $\begin{array}{c}0.132 * * \\
{[0.021]}\end{array}$ & $\begin{array}{c}0.370 * * \\
{[0.108]}\end{array}$ & $\begin{array}{c}0.130 * * \\
{[0.021]}\end{array}$ \\
\hline Cash/assets $\mathrm{t}_{\mathrm{t}-1}$ & $\begin{array}{l}0.294 * * \\
{[0.075]}\end{array}$ & $\begin{array}{l}0.228 * * \\
{[0.021]}\end{array}$ & $\begin{array}{c}0.298 * * \\
{[0.075]}\end{array}$ & $\begin{array}{l}0.226^{* *} \\
{[0.021]}\end{array}$ \\
\hline Leverage $_{t-1}$ & $\begin{array}{c}-0.062 \\
{[0.051]}\end{array}$ & $\begin{array}{c}-0.119 * * \\
{[0.014]}\end{array}$ & $\begin{array}{l}-0.063 \\
{[0.052]}\end{array}$ & $\begin{array}{c}-0.118 * * \\
{[0.014]}\end{array}$ \\
\hline $\log (\text { sales })_{\mathrm{t}-1}$ & $\begin{array}{c}0.005 \\
{[0.017]}\end{array}$ & $\begin{array}{c}-0.028 * * \\
{[0.003]}\end{array}$ & $\begin{array}{c}0.006 \\
{[0.017]}\end{array}$ & $\begin{array}{c}-0.028 * * \\
{[0.003]}\end{array}$ \\
\hline GDP growth $_{\mathrm{t}-1}$ & $\begin{array}{c}3.446 * * \\
{[1.008]}\end{array}$ & $\begin{array}{c}0.285 \\
{[0.211]}\end{array}$ & $\begin{array}{c}3.487 * * \\
{[1.144]}\end{array}$ & $\begin{array}{c}0.280 \\
{[0.210]}\end{array}$ \\
\hline $\log (\mathrm{GDP} / \text { capita })_{\mathrm{t}-1}$ & $\begin{array}{c}-0.677 * \\
{[0.340]}\end{array}$ & $\begin{array}{c}0.020 \\
{[0.062]}\end{array}$ & $\begin{array}{c}-0.627^{*} \\
{[0.318]}\end{array}$ & $\begin{array}{c}0.005 \\
{[0.061]}\end{array}$ \\
\hline $\begin{array}{l}\text { Relative change in domestic/USD } \\
\text { exchange rate } \text { t }-1^{-}\end{array}$ & $\begin{array}{l}-0.239 * \\
{[0.108]}\end{array}$ & $\begin{array}{c}0.074 * * \\
{[0.025]}\end{array}$ & $\begin{array}{c}-0.253 * * \\
{[0.088]}\end{array}$ & $\begin{array}{c}0.073 * * \\
{[0.025]}\end{array}$ \\
\hline $\begin{array}{l}\text { Absolute change in } \log (\text { firm } Q)_{\mathrm{t}-1} \\
\quad \text { (instrument) }\end{array}$ & $\begin{array}{c}0.203 * * \\
{[0.038]}\end{array}$ & & $\begin{array}{c}0.205 * * \\
{[0.039]}\end{array}$ & \\
\hline $\begin{array}{l}\text { Absolute change in } \log (\text { industry } Q)_{\mathrm{t}-1} \\
\quad \text { (instrument) }\end{array}$ & $\begin{array}{l}-0.038 \\
{[0.023]}\end{array}$ & & $\begin{array}{l}-0.037 \\
{[0.023]}\end{array}$ & \\
\hline Change in short-term interest rate $\mathrm{t}_{\mathrm{t}}$ & & & $\begin{array}{l}2.773 * \\
{[1.328]}\end{array}$ & $\begin{array}{l}-0.625^{*} \\
{[0.318]}\end{array}$ \\
\hline Change in term-spread ${ }_{t}$ & & & $\begin{array}{c}0.367 \\
{[2.010]}\end{array}$ & $\begin{array}{l}-0.350 \\
{[0.383]}\end{array}$ \\
\hline $\begin{array}{l}\text { Short-term interest rate } \mathrm{t}_{\mathrm{t}-1} \\
\quad \text { (instrument) }\end{array}$ & & & $\begin{array}{l}-1.329 \\
{[1.993]}\end{array}$ & \\
\hline $\begin{array}{l}\text { Term-spread } \\
\text { (instrument) }\end{array}$ & & & $\begin{array}{l}-2.108 \\
{[2.641]}\end{array}$ & \\
\hline Year dummies and fixed firm-effects & YES & YES & YES & YES \\
\hline Adjusted $\mathrm{R}^{2}$ excluding fixed firm effects & 0.142 & 0.148 & 0.147 & 0.145 \\
\hline Number of observations & 11,208 & 11,208 & 11,208 & 11,208 \\
\hline P-value from Sargan-test & & 0.381 & & 0.414 \\
\hline $\begin{array}{l}\text { P-value from F-test: } \\
\text { Strong euro vs. weak euro firms }\end{array}$ & 0.002 & 0.030 & 0.251 & 0.012 \\
\hline
\end{tabular}


Table 5. The introduction of the euro, firm size, and corporate investments

The sample is a balanced panel of 1401 firms from the Euro-countries (except Greece) and five Non-euro countries (Denmark, Norway, Sweden, Switzerland, and UK) with complete data in Worldscope over the time period 1995-2002. Estimation by 2SLS. The euro-countries classified as weak (i.e., countries with a recent currency crisis) are: Finland, Italy, Ireland, Portugal and Spain. The post-euro time period is defined as the years 1999-2002. A firm is classified as large if its sales are above the median sales within its country in 1997, otherwise it is classified as small. See Appendix A for other variable definitions. Standard errors are reported within brackets. * and **, indicates significance at the 5\%, and $1 \%$-levels, respectively. The Sargan-test of overidentifying restrictions is a test of the validity of the instruments under the null that the instruments are valid.

\begin{tabular}{|c|c|c|c|c|}
\hline \multirow[b]{4}{*}{ Explanatory variable: } & \multicolumn{4}{|c|}{ 2SLS regressions } \\
\hline & \multicolumn{4}{|c|}{ Dependent variable: } \\
\hline & $\frac{\text { First stage }}{\log (\text { firm } Q)_{t-1}}$ & $\frac{\text { Second stage }}{\text { Investment rate }_{\mathrm{t}}}$ & $\frac{\text { First stage }}{\log (\text { firm } Q)_{t-1}}$ & $\begin{array}{l}\text { Second stage } \\
\text { Investment rate } \\
\end{array}$ \\
\hline & (1) & $(2)$ & (3) & (4) \\
\hline $\begin{array}{l}\text { Strong euro country } \mathrm{x} \text { small firm } \mathrm{x} \\
\text { post-euro dummy }\end{array}$ & $\begin{array}{c}0.062 \\
{[0.042]}\end{array}$ & $\begin{array}{c}-0.019 * * \\
{[0.007]}\end{array}$ & $\begin{array}{c}0.052 \\
{[0.049]}\end{array}$ & $\begin{array}{l}-0.017^{*} \\
{[0.007]}\end{array}$ \\
\hline $\begin{array}{l}\text { Strong euro country } \mathrm{x} \text { large firm } \mathrm{x} \\
\text { post-euro dummy }\end{array}$ & $\begin{array}{c}0.074 \\
{[0.051]}\end{array}$ & $\begin{array}{l}-0.015^{*} \\
{[0.007]}\end{array}$ & $\begin{array}{c}0.064 \\
{[0.055]}\end{array}$ & $\begin{array}{c}-0.012 \\
{[0.007]}\end{array}$ \\
\hline $\begin{array}{l}\text { Weak euro country } \mathrm{x} \text { small firm } \mathrm{x} \\
\text { post-euro dummy }\end{array}$ & $\begin{array}{l}0.186^{* *} \\
{[0.047]}\end{array}$ & $\begin{array}{l}-0.001 \\
{[0.011]}\end{array}$ & $\begin{array}{l}0.145^{* *} \\
{[0.047]}\end{array}$ & $\begin{array}{c}0.005 \\
{[0.011]}\end{array}$ \\
\hline $\begin{array}{l}\text { Weak euro country x large firm x } \\
\text { post-euro dummy }\end{array}$ & $\begin{array}{c}0.158 * * \\
{[0.048]}\end{array}$ & $\begin{array}{c}0.002 \\
{[0.011]}\end{array}$ & $\begin{array}{l}0.116^{*} \\
{[0.047]}\end{array}$ & $\begin{array}{c}0.008 \\
{[0.011]}\end{array}$ \\
\hline Small firm x post-euro dummy & $\begin{array}{c}-0.045^{* *} \\
{[0.008]}\end{array}$ & $\begin{array}{c}0.006 \\
{[0.006]}\end{array}$ & $\begin{array}{c}-0.045^{* *} \\
{[0.008]}\end{array}$ & $\begin{array}{c}0.006 \\
{[0.006]}\end{array}$ \\
\hline $\log (\text { firm } Q)_{\mathrm{t}-1}$ (instrumented) & & $\begin{array}{l}0.126^{* *} \\
{[0.036]}\end{array}$ & & $\begin{array}{c}0.131 * * \\
{[0.035]}\end{array}$ \\
\hline $\begin{array}{l}\text { Absolute changes in } \log (\text { firm } Q)_{t-1} \text { and } \\
\log (\text { industry } Q)_{t-1} \text { as instruments }\end{array}$ & YES & & YES & \\
\hline $\begin{array}{l}\text { Change in short-term interest rate }{ }_{t} \text { and } \\
\text { change in term-spread } \text { as controls }^{\text {an }}\end{array}$ & NO & NO & YES & YES \\
\hline $\begin{array}{l}\text { Short-term interest rate } \mathrm{t}_{\mathrm{t}-\mathrm{and}} \text { and term- } \\
\text { spread }_{\mathrm{t}-1} \text { as instruments }\end{array}$ & NO & & YES & \\
\hline Firm- and country-specific controls & YES & YES & YES & YES \\
\hline Year dummies and fixed firm effects & YES & YES & YES & YES \\
\hline Adjusted $R^{2}$ excluding fixed firm effects & 0.145 & 0.148 & 0.147 & 0.148 \\
\hline Number of observations & 11,208 & 11,208 & 11,208 & 11,208 \\
\hline P-value from Sargan-test & & 0.378 & & 0.410 \\
\hline \multicolumn{5}{|l|}{ P-value from F-test: } \\
\hline $\begin{array}{l}\text { Strong euro } \mathrm{x} \text { small firm vs. } \\
\text { strong euro } \mathrm{x} \text { big firm }\end{array}$ & 0.562 & 0.608 & 0.567 & 0.611 \\
\hline $\begin{array}{l}\text { Weak euro x small firm vs. } \\
\text { weak euro x big firm }\end{array}$ & 0.296 & 0.814 & 0.286 & 0.802 \\
\hline $\begin{array}{l}\text { Strong euro } \mathrm{x} \text { small firm vs. } \\
\text { weak euro x small firm }\end{array}$ & 0.001 & 0.084 & 0.164 & 0.047 \\
\hline $\begin{array}{l}\text { Strong euro } \mathrm{x} \text { big firm vs. } \\
\text { weak euro } \mathrm{x} \text { big firm }\end{array}$ & 0.021 & 0.099 & 0.416 & 0.055 \\
\hline
\end{tabular}


Table 6. The introduction of the euro, exchange rate exposure, and corporate investments

The sample is a balanced panel of 1341 firms from the Euro-countries (except Greece) and five Non-euro countries (Denmark, Norway, Sweden, Switzerland, and UK) with complete data in Worldscope over the time period 1995-2002. Estimation by 2SLS. The euro-countries classified as weak (i.e., countries with a recent currency crisis) are: Finland, Italy, Ireland, Portugal and Spain. The post-euro time period is defined as the years 1999-2002. The euro exchange rate exposure is measured as the exchange rate beta from a two-factor model of stock returns in which changes in the (synthetic) euro exchange rate and the domestic stock market return are the two factors. The estimations of exchange rate betas (ERBs) are performed using monthly data over the time period January 1992 to December 1994. A significant positive (negative) ERB implies that the firm benefits (is hurt) when the firm's domestic currency depreciates relative to the synthetic euro. A firm is classified as having a significant (positive or negative) ERB if it is significant at the 5\%-level according to a one-sided t-test. See Appendix A for other variable definitions. Standard errors are reported within brackets. * and **, indicates significance at the $5 \%$, and $1 \%$-levels, respectively. The Sargantest of overidentifying restrictions is a test of the validity of the instruments under the null that the instruments are valid.

\begin{tabular}{|c|c|c|c|c|}
\hline \multirow[b]{4}{*}{ Explanatory variable: } & \multicolumn{4}{|c|}{ 2SLS regressions } \\
\hline & \multicolumn{4}{|c|}{ Dependent variable: } \\
\hline & $\frac{\text { First stage }}{\log [\text { firm } Q]_{t-1}}$ & $\begin{array}{c}\text { Second stage } \\
\text { Investment rate }{ }_{t}\end{array}$ & $\underline{\operatorname{First} \text { stage }}$ & $\frac{\text { Second stage }}{\text { Investment rate }_{t}}$ \\
\hline & $(1)$ & $(2)$ & $(3)$ & $(4)$ \\
\hline Strong euro country $\mathrm{x}$ post-euro dummy & $\begin{array}{c}0.064 \\
{[0.045]}\end{array}$ & $\begin{array}{c}-0.018 * * \\
{[0.006]}\end{array}$ & $\begin{array}{c}0.053 \\
{[0.051]}\end{array}$ & $\begin{array}{c}-0.015^{*} \\
{[0.006]}\end{array}$ \\
\hline $\begin{array}{l}\text { Strong euro country } \mathrm{x} \text { sign. positive ERB } \mathrm{x} \\
\text { post-euro dummy }\end{array}$ & $\begin{array}{c}-0.061 * * \\
{[0.012]}\end{array}$ & $\begin{array}{c}0.003 \\
{[0.014]}\end{array}$ & $\begin{array}{c}-0.060 * * \\
{[0.012]}\end{array}$ & $\begin{array}{c}0.004 \\
{[0.014]}\end{array}$ \\
\hline $\begin{array}{l}\text { Strong euro country x sign. negative ERB } x \\
\text { post-euro dummy }\end{array}$ & $\begin{array}{l}0.046^{*} \\
{[0.019]}\end{array}$ & $\begin{array}{l}-0.004 \\
{[0.017]}\end{array}$ & $\begin{array}{l}0.047 * \\
{[0.019]}\end{array}$ & $\begin{array}{l}-0.005 \\
{[0.017]}\end{array}$ \\
\hline Weak euro country x post-euro dummy & $\begin{array}{c}0.165 * * \\
{[0.043]}\end{array}$ & $\begin{array}{c}0.001 \\
{[0.010]}\end{array}$ & $\begin{array}{l}0.125 * * \\
{[0.045]}\end{array}$ & $\begin{array}{c}0.007 \\
{[0.009]}\end{array}$ \\
\hline $\begin{array}{l}\text { Weak euro country x sign. positive ERB x } \\
\text { post-euro dummy }\end{array}$ & $\begin{array}{l}-0.012 \\
{[0.022]}\end{array}$ & $\begin{array}{l}-0.012 \\
{[0.025]}\end{array}$ & $\begin{array}{l}-0.013 \\
{[0.022]}\end{array}$ & $\begin{array}{l}-0.012 \\
{[0.025]}\end{array}$ \\
\hline $\begin{array}{l}\text { Weak euro country x sign. negative ERB x } \\
\text { post-euro dummy }\end{array}$ & $\begin{array}{l}0.052 * \\
{[0.022]}\end{array}$ & $\begin{array}{l}-0.011 \\
{[0.017]}\end{array}$ & $\begin{array}{c}0.055 * * \\
{[0.021]}\end{array}$ & $\begin{array}{l}-0.012 \\
{[0.017]}\end{array}$ \\
\hline $\log [\text { firm } Q]_{t-1}$ (instrumented) & & $\begin{array}{c}0.135 * * \\
{[0.034]}\end{array}$ & & $\begin{array}{c}0.139 * * \\
{[0.034]}\end{array}$ \\
\hline $\begin{array}{l}\text { Absolute changes in } \log [\text { firm } Q]_{t-1} \text { and } \\
\log [\text { industry } Q]_{t-1} \text { as instruments }\end{array}$ & YES & & YES & \\
\hline $\begin{array}{l}\text { Change in short-term interest rate } \mathrm{t}_{\mathrm{t}} \text { and } \\
\text { change in term-spread } \text { as controls }^{\text {as }}\end{array}$ & NO & NO & YES & YES \\
\hline $\begin{array}{l}\text { Short-term interest rate }_{\mathrm{t}-1} \text { and term- } \text { spread }_{\mathrm{t}-} \\
{ }_{1} \text { as instruments }\end{array}$ & NO & & YES & \\
\hline Firm- and country-specific controls & YES & YES & YES & YES \\
\hline Year dummies and fixed firm effects & YES & YES & YES & YES \\
\hline Adjusted $\mathrm{R}^{2}$ excluding fixed firm effects & 0.144 & 0.138 & 0.146 & 0.140 \\
\hline Number of observations & 10,722 & 10,722 & 10,722 & 10,722 \\
\hline P-value from Sargan-test & & 0.299 & & 0.396 \\
\hline \multicolumn{5}{|l|}{ P-value from F-test: } \\
\hline $\begin{array}{c}\text { Strong euro } \mathrm{x} \text { significant positive ERB vs. } \\
\text { strong euro } \mathrm{x} \text { significant negative ERB }\end{array}$ & 0.000 & 0.715 & 0.000 & 0.692 \\
\hline $\begin{array}{l}\text { Weak euro x significant positive ERB vs. } \\
\text { weak euro x negative ERB }\end{array}$ & 0.007 & 0.964 & 0.001 & 0.995 \\
\hline $\begin{array}{l}\text { Strong euro } \mathrm{x} \text { significant positive ERB vs. } \\
\text { weak euro x significant positive ERB }\end{array}$ & 0.062 & 0.592 & 0.074 & 0.593 \\
\hline $\begin{array}{l}\text { Strong euro } \mathrm{x} \text { significant negative ERB vs. } \\
\text { weak euro } \mathrm{x} \text { negative ERB }\end{array}$ & 0.835 & 0.784 & 0.748 & 0.772 \\
\hline
\end{tabular}




\section{Table 7. The introduction of the euro, financial constraints, and corporate investments}

The sample is a balanced panel of 1401 firms from the Euro-countries (except Greece) and five Non-euro countries (Denmark, Norway, Sweden, Switzerland, and UK) with complete data in Worldscope over the time period 1995-2002. Estimation by 2SLS. The euro-countries classified as weak (i.e., countries with a recent currency crisis) are: Finland, Italy, Ireland, Portugal and Spain. The post-euro time period is defined as the years 1999-2002. We calculate an index of financial constraints based on Kaplan and Zingales (1997). In particular, we use the following formula to compute a KZ-index of financial constraints: $K Z_{i t}=-1.002$

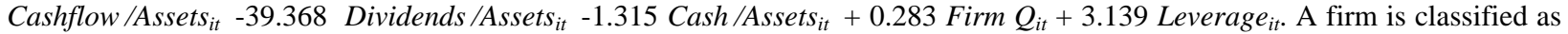
constrained if its KZ-index is above the median KZ-index within its country in 1997, otherwise it is classified as unconstrained. See Appendix A for other variable definitions. Standard errors are reported within brackets. * and **, indicates significance at the $5 \%$, and $1 \%$-levels, respectively. The Sargan-test of overidentifying restrictions is a test of the validity of the instruments under the null that the instruments are valid.

\begin{tabular}{|c|c|c|c|c|}
\hline \multirow[b]{4}{*}{ Explanatory variable: } & \multicolumn{4}{|c|}{ 2SLS regressions } \\
\hline & \multicolumn{4}{|c|}{ Dependent variable: } \\
\hline & $\frac{\text { First stage }}{\log (\text { firm Q })_{\mathrm{t}-1}}$ & $\begin{array}{l}\text { Second stage } \\
\text { Investment rate }_{t}\end{array}$ & $\frac{\text { First stage }}{\log (\text { firm Q })_{\mathrm{t}-1}}$ & $\begin{array}{l}\text { Second stage } \\
\text { Investment rate }_{\mathrm{t}}\end{array}$ \\
\hline & $(1)$ & $(2)$ & $(3)$ & $(4)$ \\
\hline $\begin{array}{l}\text { Strong euro country } \mathrm{x} \text { constrained firm } \\
\mathrm{x} \text { post-euro dummy }\end{array}$ & $\begin{array}{c}0.044 \\
{[0.032]}\end{array}$ & $\begin{array}{l}-0.005 \\
{[0.007]}\end{array}$ & $\begin{array}{c}0.035 \\
{[0.043]}\end{array}$ & $\begin{array}{c}-0.002 \\
{[0.007]}\end{array}$ \\
\hline $\begin{array}{l}\text { Strong euro country } \mathrm{x} \text { unconstrained firm } \\
\mathrm{x} \text { post-euro dummy }\end{array}$ & $\begin{array}{c}0.090 \\
{[0.062]}\end{array}$ & $\begin{array}{c}-0.030 * * \\
{[0.007]}\end{array}$ & $\begin{array}{c}0.081 \\
{[0.065]}\end{array}$ & $\begin{array}{c}-0.027 * * \\
{[0.007]}\end{array}$ \\
\hline $\begin{array}{l}\text { Weak euro country } \mathrm{x} \text { constrained firm } \\
\mathrm{x} \text { post-euro dummy }\end{array}$ & $\begin{array}{l}0.124 * * \\
{[0.038]}\end{array}$ & $\begin{array}{c}0.019 \\
{[0.010]}\end{array}$ & $\begin{array}{l}0.082 * \\
{[0.038]}\end{array}$ & $\begin{array}{l}0.025^{*} \\
{[0.010]}\end{array}$ \\
\hline $\begin{array}{l}\text { Weak euro country } \mathrm{x} \text { unconstrained firm } \\
\mathrm{x} \text { post-euro dummy }\end{array}$ & $\begin{array}{l}0.221 * * \\
{[0.064]}\end{array}$ & $\begin{array}{l}-0.018 \\
{[0.012]}\end{array}$ & $\begin{array}{l}0.179 * * \\
{[0.063]}\end{array}$ & $\begin{array}{c}-0.012 \\
{[0.012]}\end{array}$ \\
\hline Constrained firm x post-euro dummy & $\begin{array}{c}0.054 \\
{[0.035]}\end{array}$ & $\begin{array}{c}-0.039 * * \\
{[0.006]}\end{array}$ & $\begin{array}{c}0.054 \\
{[0.035]}\end{array}$ & $\begin{array}{c}-0.040 * * \\
{[0.006]}\end{array}$ \\
\hline $\log (\text { firm Q) })_{t-1}$ (instrumented) & & $\begin{array}{l}0.128 * * \\
{[0.036]}\end{array}$ & & $\begin{array}{l}0.132 * * \\
{[0.035]}\end{array}$ \\
\hline $\begin{array}{l}\text { Absolute changes in } \log (\text { firm } Q)_{t-1} \text { and } \\
\log (\text { industry } Q)_{t-1} \text { as instruments }\end{array}$ & YES & & YES & \\
\hline $\begin{array}{l}\text { Change in short-term interest rate } e_{\mathrm{t}} \text { and } \\
\text { change in term-spread } \text { as controls }^{\text {as }}\end{array}$ & NO & NO & YES & YES \\
\hline $\begin{array}{l}\text { Short-term interest rate }{ }_{t-1} \text { and term- } \\
\text { spread }_{t-1} \text { as instruments }\end{array}$ & NO & & YES & \\
\hline Firm- and country-specific controls & YES & YES & YES & YES \\
\hline Year dummies and fixed firm effects & YES & YES & YES & YES \\
\hline Adjusted $\mathrm{R}^{2}$ excluding fixed firm effects & 0.144 & 0.152 & 0.147 & 0.151 \\
\hline Number of observations & 11,208 & 11,208 & 11,208 & 11,208 \\
\hline P-value from Sargan-test & & 0.390 & & 0.401 \\
\hline \multicolumn{5}{|l|}{ P-value from F-test: } \\
\hline $\begin{array}{l}\text { Strong euro } \mathrm{x} \text { constrained firm vs. } \\
\text { strong euro } \mathrm{x} \text { unconstrained firm }\end{array}$ & 0.270 & 0.009 & 0.273 & 0.008 \\
\hline $\begin{array}{l}\text { Weak euro } \mathrm{x} \text { constrained firm vs. } \\
\text { weak euro } \mathrm{x} \text { unconstrained firm }\end{array}$ & 0.066 & 0.006 & 0.066 & 0.005 \\
\hline $\begin{array}{l}\text { Strong euro x constrained firm vs. } \\
\text { weak euro } \mathrm{x} \text { constrained firm }\end{array}$ & 0.052 & 0.022 & 0.476 & 0.010 \\
\hline $\begin{array}{l}\text { Strong euro } \mathrm{x} \text { unconstrained firm vs. } \\
\text { weak euro } \mathrm{x} \text { unconstrained firm }\end{array}$ & 0.001 & 0.283 & 0.151 & 0.184 \\
\hline
\end{tabular}


Table 8. The introduction of the euro, financial constraints, public debt issues, and corporate investments

The sample is a balanced panel of 1401 firms from the Euro-countries (except Greece) and five Non-euro countries (Denmark, Norway, Sweden, Switzerland, and UK) with complete data in Worldscope over the time period 1995-2002. Estimation by 2SLS. The euro-countries classified as weak (i.e., countries with a recent currency crisis) are: Finland, Italy, Ireland, Portugal and Spain. The post-euro time period is defined as the years 1999-2002. We calculate an index of financial constraints based on Kaplan and Zingales (1997). In particular, we use the following formula to compute a KZ-index of financial constraints: $K Z_{i t}=-1.002$

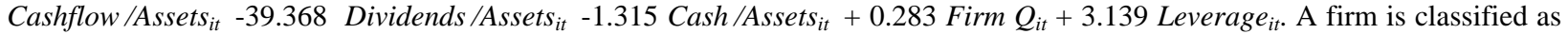
constrained if its KZ-index is above the median KZ-index within its country in 1997, otherwise it is classified as unconstrained. See Appendix A for other variable definitions. Standard errors are reported within brackets. * and **, indicates significance at the $5 \%$, and $1 \%$-levels, respectively. The Sargan-test of overidentifying restrictions is a test of the validity of the instruments under the null that the instruments are valid.

Panel A: The effect of bond issues

\begin{tabular}{|c|c|c|c|c|}
\hline \multirow[b]{4}{*}{ Explanatory variable: } & \multicolumn{4}{|c|}{ 2SLS regressions } \\
\hline & \multicolumn{4}{|c|}{ Dependent variable: } \\
\hline & $\frac{\text { First stage }}{\log (\text { firm Q })_{\mathrm{t}-1}}$ & $\begin{array}{l}\text { Second stage } \\
\text { Investment rate }_{t}\end{array}$ & $\frac{\text { First stage }}{\log (\text { firm } Q)_{\mathrm{t}-1}}$ & $\begin{array}{l}\text { Second stage } \\
\text { Investment rate }_{\mathrm{t}}\end{array}$ \\
\hline & $(1)$ & $(2)$ & $(3)$ & $(4)$ \\
\hline $\begin{array}{l}\text { Strong euro country } \mathrm{x} \text { constrained firm } \\
\mathrm{x} \text { post-euro dummy }\end{array}$ & $\begin{array}{c}0.044 \\
{[0.032]}\end{array}$ & $\begin{array}{l}-0.005 \\
{[0.007]}\end{array}$ & $\begin{array}{c}0.034 \\
{[0.043]}\end{array}$ & $\begin{array}{l}-0.003 \\
{[0.007]}\end{array}$ \\
\hline $\begin{array}{l}\text { Strong euro country } \mathrm{x} \text { unconstrained firm } \\
\mathrm{x} \text { post-euro dummy }\end{array}$ & $\begin{array}{c}0.090 \\
{[0.062]}\end{array}$ & $\begin{array}{c}-0.029 * * \\
{[0.007]}\end{array}$ & $\begin{array}{c}0.081 \\
{[0.065]}\end{array}$ & $\begin{array}{c}-0.027 * * \\
{[0.007]}\end{array}$ \\
\hline $\begin{array}{l}\text { Weak euro country } \mathrm{x} \text { constrained firm } \\
\mathrm{x} \text { post-euro dummy }\end{array}$ & $\begin{array}{c}0.123 * * \\
{[0.038]}\end{array}$ & $\begin{array}{c}0.019 \\
{[0.010]}\end{array}$ & $\begin{array}{l}0.080^{*} \\
{[0.038]}\end{array}$ & $\begin{array}{c}0.024^{*} \\
{[0.010]}\end{array}$ \\
\hline $\begin{array}{l}\text { Weak euro country } \mathrm{x} \text { unconstrained firm } \\
\mathrm{x} \text { post-euro dummy }\end{array}$ & $\begin{array}{c}0.221 * * \\
{[0.064]}\end{array}$ & $\begin{array}{l}-0.017 \\
{[0.012]}\end{array}$ & $\begin{array}{l}0.180^{* *} \\
{[0.063]}\end{array}$ & $\begin{array}{c}-0.012 \\
{[0.012]}\end{array}$ \\
\hline Constrained firm x post-euro dummy & $\begin{array}{c}0.054 \\
{[0.035]}\end{array}$ & $\begin{array}{c}-0.039 * * \\
{[0.006]}\end{array}$ & $\begin{array}{c}0.054 \\
{[0.035]}\end{array}$ & $\begin{array}{c}-0.039 * * \\
{[0.006]}\end{array}$ \\
\hline Public debt issue dummy & $\begin{array}{c}0.034 \\
{[0.021]}\end{array}$ & $\begin{array}{l}0.023 * * \\
{[0.008]}\end{array}$ & $\begin{array}{c}0.035 \\
{[0.020]}\end{array}$ & $\begin{array}{c}0.023 * * \\
{[0.008]}\end{array}$ \\
\hline $\log (\text { firm } Q)_{t-1}$ (instrumented) & & $\begin{array}{l}0.126 * * \\
{[0.036]}\end{array}$ & & $\begin{array}{l}0.131 * * \\
{[0.035]}\end{array}$ \\
\hline $\begin{array}{l}\text { Absolute changes in } \log (\text { firm } Q)_{t-1} \text { and } \\
\log (\text { industry } Q)_{t-1} \text { as instruments }\end{array}$ & YES & & YES & \\
\hline $\begin{array}{l}\text { Change in short-term interest rate } \mathrm{t}_{\mathrm{t}} \text { and } \\
\text { change in term-spread } \text { as controls }^{\text {a }}\end{array}$ & NO & NO & YES & YES \\
\hline $\begin{array}{l}\text { Short-term interest rate } \\
\text { spread }_{\mathrm{t}-1} \text { and term- } \\
\text { anstruments }\end{array}$ & NO & & YES & \\
\hline Firm- and country-specific controls & YES & YES & YES & YES \\
\hline Year dummies and fixed firm effects & YES & YES & YES & YES \\
\hline Adjusted $\mathrm{R}^{2}$ excluding fixed firm effects & 0.144 & 0.153 & 0.146 & 0.148 \\
\hline Number of observations & 11,208 & 11,208 & 11,208 & 11,208 \\
\hline P-value from Sargan-test & & 0.397 & & 0.385 \\
\hline \multicolumn{5}{|l|}{ P-value from F-test: } \\
\hline $\begin{array}{l}\text { Strong euro } \mathrm{x} \text { constrained firm vs. } \\
\text { strong euro } \mathrm{x} \text { unconstrained firm }\end{array}$ & 0.258 & 0.010 & 0.260 & 0.011 \\
\hline $\begin{array}{l}\text { Weak euro } \mathrm{x} \text { constrained firm vs. } \\
\text { weak euro } \mathrm{x} \text { unconstrained firm }\end{array}$ & 0.061 & 0.007 & 0.062 & 0.008 \\
\hline $\begin{array}{l}\text { Strong euro } \mathrm{x} \text { constrained firm vs. } \\
\text { weak euro x constrained firm }\end{array}$ & 0.051 & 0.022 & 0.486 & 0.019 \\
\hline $\begin{array}{l}\text { Strong euro } \mathrm{x} \text { unconstrained firm vs. } \\
\text { weak euro } \mathrm{x} \text { unconstrained firm }\end{array}$ & 0.001 & 0.269 & 0.168 & 0.233 \\
\hline
\end{tabular}


Panel B: Interaction between bond issues and financial constraints

\begin{tabular}{|c|c|c|c|c|}
\hline \multirow[b]{4}{*}{ Explanatory variable: } & \multicolumn{4}{|c|}{ 2SLS regressions } \\
\hline & \multicolumn{4}{|c|}{ Dependent variable: } \\
\hline & $\frac{\text { First stage }}{\log (\text { firm Q })_{\mathrm{t}-1}}$ & $\begin{array}{c}\text { Second stage } \\
\text { Investment rate }\end{array}$ & $\frac{\text { First stage }}{\log (\text { firm } Q)_{t-1}}$ & $\frac{\text { Second stage }}{\text { Investment rate }_{\mathrm{t}}}$ \\
\hline & $(1)$ & $(2)$ & $(3)$ & (4) \\
\hline $\begin{array}{l}\text { Strong euro country } \mathrm{x} \text { constrained firm } \\
\mathrm{x} \text { post-euro dummy }\end{array}$ & $\begin{array}{c}0.033 \\
{[0.029]}\end{array}$ & $\begin{array}{l}-0.007 \\
{[0.007]}\end{array}$ & $\begin{array}{c}0.024 \\
{[0.041]}\end{array}$ & $\begin{array}{c}-0.004 \\
{[0.007]}\end{array}$ \\
\hline $\begin{array}{l}\text { Strong euro country } \mathrm{x} \text { unconstrained firm } \\
\mathrm{x} \text { post-euro dummy }\end{array}$ & $\begin{array}{c}0.091 \\
{[0.063]}\end{array}$ & $\begin{array}{c}-0.029 * * \\
{[0.007]}\end{array}$ & $\begin{array}{c}0.081 \\
{[0.065]}\end{array}$ & $\begin{array}{c}-0.027 * * \\
{[0.008]}\end{array}$ \\
\hline $\begin{array}{l}\text { Weak euro country } \mathrm{x} \text { constrained firm } \\
\mathrm{x} \text { post-euro dummy }\end{array}$ & $\begin{array}{c}0.118 * * \\
{[0.038]}\end{array}$ & $\begin{array}{c}0.020 \\
{[0.010]}\end{array}$ & $\begin{array}{l}0.077 * \\
{[0.038]}\end{array}$ & $\begin{array}{c}0.025^{*} \\
{[0.010]}\end{array}$ \\
\hline $\begin{array}{l}\text { Weak euro country } \mathrm{x} \text { unconstrained firm } \\
\mathrm{x} \text { post-euro dummy }\end{array}$ & $\begin{array}{c}0.222 * * \\
{[0.064]}\end{array}$ & $\begin{array}{l}-0.017 \\
{[0.012]}\end{array}$ & $\begin{array}{l}0.180 * * \\
{[0.063]}\end{array}$ & $\begin{array}{c}-0.012 \\
{[0.012]}\end{array}$ \\
\hline Constrained firm x post-euro dummy & $\begin{array}{c}0.056 \\
{[0.037]}\end{array}$ & $\begin{array}{c}-0.037 * * \\
{[0.006]}\end{array}$ & $\begin{array}{c}0.056 \\
{[0.037]}\end{array}$ & $\begin{array}{c}-0.038 * * \\
{[0.006]}\end{array}$ \\
\hline Public debt issue dummy & $\begin{array}{c}0.015 \\
{[0.019]}\end{array}$ & $\begin{array}{c}0.035^{* *} \\
{[0.010]}\end{array}$ & $\begin{array}{c}0.018 \\
{[0.018]}\end{array}$ & $\begin{array}{l}0.035^{* *} \\
{[0.010]}\end{array}$ \\
\hline $\begin{array}{l}\text { Public debt issue } \mathrm{x} \text { strong euro country } \\
\mathrm{x} \text { constrained firm } \mathrm{x} \text { post-euro dummy }\end{array}$ & $\begin{array}{c}0.224 * * \\
{[0.080]}\end{array}$ & $\begin{array}{l}0.057^{*} \\
{[0.029]}\end{array}$ & $\begin{array}{c}0.225^{* *} \\
{[0.080]}\end{array}$ & $\begin{array}{c}0.056 \\
{[0.029]}\end{array}$ \\
\hline $\begin{array}{l}\text { Public debt issue } \mathrm{x} \text { weak euro country } \\
\mathrm{x} \text { constrained firm } \mathrm{x} \text { post-euro dummy }\end{array}$ & $\begin{array}{c}0.139 \\
{[0.096]}\end{array}$ & $\begin{array}{c}0.004 \\
{[0.035]}\end{array}$ & $\begin{array}{c}0.137 \\
{[0.095]}\end{array}$ & $\begin{array}{c}0.003 \\
{[0.035]}\end{array}$ \\
\hline $\begin{array}{l}\text { Public debt issue } \mathrm{x} \text { constrained firm } \\
\mathrm{x} \text { post-euro dummy }\end{array}$ & $\begin{array}{l}-0.087 \\
{[0.081]}\end{array}$ & $\begin{array}{l}-0.059 * \\
{[0.023]}\end{array}$ & $\begin{array}{l}-0.090 \\
{[0.079]}\end{array}$ & $\begin{array}{l}-0.058^{*} \\
{[0.023]}\end{array}$ \\
\hline $\log (\text { firm } Q)_{\mathrm{t}-1}($ instrumented $)$ & & $\begin{array}{l}0.125 * * \\
{[0.036]}\end{array}$ & & $\begin{array}{l}0.130 * * \\
{[0.035]}\end{array}$ \\
\hline $\begin{array}{l}\text { Absolute changes in } \log (\text { firm } Q)_{t-1} \text { and } \\
\log (\text { industry } Q)_{t-1} \text { as instruments }\end{array}$ & YES & & YES & \\
\hline $\begin{array}{l}\text { Change in short-term interest rate }{ }_{t} \text { and } \\
\text { change in term-spread } \text { as controls }^{\text {a }}\end{array}$ & NO & NO & YES & YES \\
\hline $\begin{array}{l}\text { Short-term interest rate } \mathrm{t}_{\mathrm{t}-1} \text { and term- } \\
\text { spread }_{\mathrm{t}-1} \text { as instruments }\end{array}$ & NO & & YES & \\
\hline Firm- and country-specific controls & YES & YES & YES & YES \\
\hline Year dummies and fixed firm effects & YES & YES & YES & YES \\
\hline Adjusted $\mathrm{R}^{2}$ excluding fixed firm effects & 0.146 & 0.154 & 0.150 & 0.153 \\
\hline Number of observations & 11,208 & 11,208 & 11,208 & 11,208 \\
\hline P-value from Sargan-test & & 0.387 & & 0.351 \\
\hline
\end{tabular}


Table 9. The introduction of the euro and corporate investments: Anticipation effects

The sample is a balanced panel of 1401 firms from the Euro-countries (except Greece) and five Non-euro countries (Denmark, Norway, Sweden, Switzerland, and UK) with complete data in Worldscope over the time period 1995-2002. Estimation by 2SLS. The euro-countries classified as weak (i.e., countries with a recent currency crisis) are: Finland, Italy, Ireland, Portugal and Spain. To test for anticipation effects of the introduction of the euro, we interact dummies indicating whether a firm belongs to a strong or weak euro country with two time-period dummies; (i) a dummy indicating if the time period is 1998 and later, and (ii) a dummy indicating the time period is 1999 and after. See Appendix A for other variable definitions. Standard errors are reported within brackets. $*$ and $* *$, indicates significance at the $5 \%$, and $1 \%$-levels, respectively. The Sargan-test of overidentifying restrictions is a test of the validity of the instruments under the null that the instruments are valid.

\begin{tabular}{|c|c|c|c|c|}
\hline \multirow[b]{4}{*}{ Explanatory variable: } & \multicolumn{4}{|c|}{ 2SLS regressions } \\
\hline & \multicolumn{4}{|c|}{ Dependent variable: } \\
\hline & $\frac{\text { First stage }}{\log (\text { firm Q })_{\mathrm{t}-1}}$ & $\begin{array}{c}\text { Second stage } \\
\text { Investment rate }_{t}\end{array}$ & $\frac{\text { First stage }}{\log (\text { firm } Q)_{t-1}}$ & $\begin{array}{c}\text { Second stage } \\
\text { Investment rate }_{t}\end{array}$ \\
\hline & $(1)$ & $(2)$ & $(3)$ & (4) \\
\hline $\begin{array}{l}\text { Strong euro country x } 1998 \text { and later } \\
\text { time period dummy }\end{array}$ & $\begin{array}{l}-0.050 \\
{[0.028]}\end{array}$ & $\begin{array}{c}0.001 \\
{[0.008]}\end{array}$ & $\begin{array}{l}-0.065 \\
{[0.035]}\end{array}$ & $\begin{array}{c}0.003 \\
{[0.008]}\end{array}$ \\
\hline $\begin{array}{l}\text { Strong euro country x } 1999 \text { and later } \\
\text { time period dummy }\end{array}$ & $\begin{array}{l}0.104 * \\
{[0.046]}\end{array}$ & $\begin{array}{l}-0.018 * \\
{[0.008]}\end{array}$ & $\begin{array}{c}0.100 \\
{[0.059]}\end{array}$ & $\begin{array}{l}-0.016 \\
{[0.009]}\end{array}$ \\
\hline $\begin{array}{l}\text { Weak euro country x } 1998 \text { and later } \\
\text { time period dummy }\end{array}$ & $\begin{array}{c}0.024 \\
{[0.028]}\end{array}$ & $\begin{array}{c}0.004 \\
{[0.011]}\end{array}$ & $\begin{array}{c}0.023 \\
{[0.077]}\end{array}$ & $\begin{array}{c}0.003 \\
{[0.012]}\end{array}$ \\
\hline $\begin{array}{l}\text { Weak euro country x } 1999 \text { and later } \\
\text { time period dummy }\end{array}$ & $\begin{array}{c}0.158^{* *} \\
{[0.050]}\end{array}$ & $\begin{array}{c}-0.002 \\
{[0.012]}\end{array}$ & $\begin{array}{l}0.119^{*} \\
{[0.054]}\end{array}$ & $\begin{array}{c}0.005 \\
{[0.012]}\end{array}$ \\
\hline $\log (\text { firm } Q)_{t-1}$ (instrumented) & & $\begin{array}{l}0.126 * * \\
{[0.036]}\end{array}$ & & $\begin{array}{l}0.128 * * \\
{[0.035]}\end{array}$ \\
\hline $\begin{array}{l}\text { Absolute changes in } \log (\text { firm } Q)_{t-1} \text { and } \\
\log (\text { industry } Q)_{t-1} \text { as instruments }\end{array}$ & YES & & YES & \\
\hline $\begin{array}{l}\text { Change in short-term interest rate } \mathrm{t}_{\mathrm{t}} \text { and } \\
\text { change in term-spread } \text { as controls }^{\text {a }}\end{array}$ & NO & NO & YES & YES \\
\hline $\begin{array}{l}\text { Short-term interest rate }{ }_{\mathrm{t}-1} \text { and term- } \\
\text { spread }_{\mathrm{t}-1} \text { as instruments }\end{array}$ & NO & & YES & \\
\hline Firm- and country-specific controls & YES & YES & YES & YES \\
\hline Year dummies and fixed firm effects & YES & YES & YES & YES \\
\hline Adjusted $\mathrm{R}^{2}$ excluding fixed firm effects & 0.143 & 0.148 & 0.148 & 0.147 \\
\hline Number of observations & 11,208 & 11,208 & 11,208 & 11,208 \\
\hline \multicolumn{5}{|l|}{ P-value from F-test: } \\
\hline $\begin{array}{l}\text { [Strong euro x } 1998 \text { and later + Strong } \\
\text { euro x } 1999 \text { and later }]=0\end{array}$ & 0.230 & 0.004 & 0.450 & 0.025 \\
\hline $\begin{array}{l}\text { [Weak euro x } 1998 \text { and later + Weak } \\
\text { euro x } 1999 \text { and later] = 0 }\end{array}$ & 0.000 & 0.847 & 0.020 & 0.419 \\
\hline P-value from Sargan-test & & 0.384 & & 0.364 \\
\hline
\end{tabular}




\section{Table 10. The introduction of the euro and corporate investments: Industry effects}

The sample is a balanced panel of 1401 firms from the Euro-countries (except Greece) and five Non-euro countries (Denmark, Norway, Sweden, Switzerland, and UK) with complete data in Worldscope over the time period 1995-2002. Estimation by 2SLS. The euro-countries classified as weak (i.e., countries with a recent currency crisis) are: Finland, Italy, Ireland, Portugal and Spain. The post-euro time period is defined as the years 1999-2002. The industry classification is based on two-digit SIC codes (manufacturing industry = SIC codes 20-39; trade industry = SIC codes 50-59; services industry = SIC codes 70-89; transportation, communications, and utilities industry = SIC codes 40-49; basic industry = SIC codes 1-19). See Appendix A for other variable definitions. Standard errors are reported within brackets. $*$ and $* *$, indicates significance at the $5 \%$, and $1 \%$-levels, respectively. The Sargan-test of overidentifying restrictions is a test of the validity of the instruments under the null that the instruments are valid.

\begin{tabular}{|c|c|c|c|c|}
\hline \multirow[b]{4}{*}{ Explanatory variable: } & \multicolumn{4}{|c|}{ 2SLS regressions } \\
\hline & \multicolumn{4}{|c|}{ Dependent variable: } \\
\hline & $\frac{\text { First stage }}{\log (\text { firm Q })_{\mathrm{t}-1}}$ & $\begin{array}{c}\text { Second stage } \\
\text { Investment rate }\end{array}$ & $\frac{\text { First stage }}{\log (\text { firm } Q)_{t-1}}$ & $\frac{\text { Second stage }}{\text { Investment rate }_{\mathrm{t}}}$ \\
\hline & $(1)$ & $(2)$ & $(3)$ & (4) \\
\hline $\begin{array}{l}\text { Strong euro country } \mathrm{x} \text { manufacturing } \mathrm{x} \\
\text { post-euro dummy }\end{array}$ & $\begin{array}{c}0.055 \\
{[0.060]}\end{array}$ & $\begin{array}{l}-0.004 \\
{[0.007]}\end{array}$ & $\begin{array}{c}0.045 \\
{[0.063]}\end{array}$ & $\begin{array}{l}-0.001 \\
{[0.007]}\end{array}$ \\
\hline $\begin{array}{l}\text { Strong euro country } \mathrm{x} \text { trade } \mathrm{x} \\
\text { post-euro dummy }\end{array}$ & $\begin{array}{c}0.072 \\
{[0.061]}\end{array}$ & $\begin{array}{c}-0.032 * * \\
{[0.012]}\end{array}$ & $\begin{array}{c}0.058 \\
{[0.064]}\end{array}$ & $\begin{array}{r}-0.029 * \\
{[0.012]}\end{array}$ \\
\hline $\begin{array}{l}\text { Strong euro country } \mathrm{x} \text { services } \mathrm{x} \\
\text { post-euro dummy }\end{array}$ & $\begin{array}{c}0.134 \\
{[0.096]}\end{array}$ & $\begin{array}{c}-0.046 * * \\
{[0.016]}\end{array}$ & $\begin{array}{c}0.118 \\
{[0.097]}\end{array}$ & $\begin{array}{c}-0.042 * * \\
{[0.016]}\end{array}$ \\
\hline $\begin{array}{l}\text { Strong euro country } \mathrm{x} \text { communications, } \\
\text { transportation, and utilities x post-euro } \\
\text { dummy }\end{array}$ & $\begin{array}{c}0.143 * * \\
{[0.031]}\end{array}$ & $\begin{array}{c}-0.068 * * \\
{[0.016]}\end{array}$ & $\begin{array}{l}0.131 * * \\
{[0.047]}\end{array}$ & $\begin{array}{c}-0.066^{* *} \\
{[0.016]}\end{array}$ \\
\hline $\begin{array}{l}\text { Strong euro country } \mathrm{x} \text { basic industry } \mathrm{x} \\
\text { post-euro dummy }\end{array}$ & $\begin{array}{c}0.051 \\
{[0.056]}\end{array}$ & $\begin{array}{l}-0.010 \\
{[0.017]}\end{array}$ & $\begin{array}{c}0.039 \\
{[0.055]}\end{array}$ & $\begin{array}{l}-0.007 \\
{[0.017]}\end{array}$ \\
\hline $\begin{array}{l}\text { Weak euro country } \mathrm{x} \text { manufacturing } \\
\text { industry } \mathrm{x} \text { post-euro dummy }\end{array}$ & $\begin{array}{l}0.152^{*} \\
{[0.062]}\end{array}$ & $\begin{array}{c}0.006 \\
{[0.011]}\end{array}$ & $\begin{array}{l}0.114^{*} \\
{[0.055]}\end{array}$ & $\begin{array}{c}0.011 \\
{[0.010]}\end{array}$ \\
\hline $\begin{array}{l}\text { Weak euro country } \mathrm{x} \text { trade industry } \mathrm{x} \\
\text { post-euro dummy }\end{array}$ & $\begin{array}{l}0.092^{*} \\
{[0.043]}\end{array}$ & $\begin{array}{l}-0.031 \\
{[0.020]}\end{array}$ & $\begin{array}{c}0.053 \\
{[0.042]}\end{array}$ & $\begin{array}{l}-0.024 \\
{[0.020]}\end{array}$ \\
\hline $\begin{array}{l}\text { Weak euro country x services industry } \mathrm{x} \\
\text { post-euro dummy }\end{array}$ & $\begin{array}{l}0.365^{* *} * \\
{[0.103]}\end{array}$ & $\begin{array}{c}0.022 \\
{[0.027]}\end{array}$ & $\begin{array}{l}0.323 * * \\
{[0.101]}\end{array}$ & $\begin{array}{c}0.028 \\
{[0.027]}\end{array}$ \\
\hline $\begin{array}{l}\text { Weak euro country x communications, } \\
\text { transportation, and utilities x post-euro } \\
\text { dummy }\end{array}$ & $\begin{array}{l}0.259 * * \\
{[0.050]}\end{array}$ & $\begin{array}{l}-0.011 \\
{[0.021]}\end{array}$ & $\begin{array}{l}0.219 * * \\
{[0.057]}\end{array}$ & $\begin{array}{l}-0.006 \\
{[0.021]}\end{array}$ \\
\hline $\begin{array}{l}\text { Weak euro country } x \text { basic industry } x \\
\text { post-euro dummy }\end{array}$ & $\begin{array}{c}0.205 * * \\
{[0.059]}\end{array}$ & $\begin{array}{l}-0.003 \\
{[0.020]}\end{array}$ & $\begin{array}{l}0.160^{*} \\
{[0.067]}\end{array}$ & $\begin{array}{c}0.004 \\
{[0.020]}\end{array}$ \\
\hline $\log (\text { firm } Q)_{\mathrm{t}-1}($ instrumented $)$ & & $\begin{array}{l}0.122 * * \\
{[0.037]}\end{array}$ & & $\begin{array}{c}0.125 * * * \\
{[0.036]}\end{array}$ \\
\hline $\begin{array}{l}\text { Interactions between industry dummies } \\
\text { and post-euro dummy }\end{array}$ & YES & YES & YES & YES \\
\hline $\begin{array}{l}\text { Absolute changes in } \log (\text { firm } Q)_{t-1} \text { and } \\
\log (\text { industry } Q)_{t-1} \text { as instruments }\end{array}$ & YES & & YES & \\
\hline $\begin{array}{l}\text { Change in short-term interest rate }{ }_{t} \text { and } \\
\text { change in term-spread } \text { as controls }^{\text {a }}\end{array}$ & NO & NO & YES & YES \\
\hline $\begin{array}{l}\text { Short-term interest rate } \\
\text { spread }_{\mathrm{t}-1} \text { as instruments }\end{array}$ & NO & & YES & \\
\hline Firm- and country-specific controls & YES & YES & YES & YES \\
\hline Year dummies and fixed firm effects & YES & YES & YES & YES \\
\hline Adjusted $\mathrm{R}^{2}$ excluding fixed firm effects & 0.151 & 0.153 & 0.155 & 0.153 \\
\hline Number of observations & 11,208 & 11,208 & 11,208 & 11,208 \\
\hline P-value from Sargan-test & & 0.107 & & 0.204 \\
\hline
\end{tabular}


Table 11. The introduction of the euro and corporate investments: Robustness to excluding big countries

In Panel A the sample is a balanced panel of 583 firms from the Euro-countries (except Greece, France and Germany) and four Non-euro countries (Denmark, Norway, Sweden, and Switzerland) with complete data in Worldscope over the time period 19952002. In Panel B the sample is a balanced panel of 1,027 firms from the Euro-countries (except Greece, France and Germany) and five Non-euro countries (Denmark, Norway, Sweden, Switzerland, and UK) with complete data in Worldscope over the time period 1995-2002. Estimation by 2SLS. The euro-countries classified as weak (i.e., countries with a recent currency crisis) are: Finland, Italy, Ireland, Portugal and Spain. The post-euro time period is defined as the years 1999-2002. See Appendix A for other variable definitions. Standard errors are reported within brackets. $*$ and $* *$, indicates significance at the $5 \%$, and $1 \%$-levels, respectively. The Sargan-test of overidentifying restrictions is a test of the validity of the instruments under the null that the instruments are valid.

$\underline{\text { Panel A: Excluding UK, France and Germany }}$

\begin{tabular}{|c|c|c|c|c|}
\hline \multirow[b]{4}{*}{ Explanatory variable: } & \multicolumn{4}{|c|}{ 2SLS regressions } \\
\hline & \multicolumn{4}{|c|}{ Dependent variable: } \\
\hline & $\frac{\text { First stage }}{\log (\text { firm } Q)_{\mathrm{t}-1}}$ & $\begin{array}{l}\text { Second stage } \\
\text { Investment rate }\end{array}$ & $\frac{\text { First stage }}{\log (\text { firm Q })_{\mathrm{t}-1}}$ & $\begin{array}{l}\text { Second stage } \\
\text { Investment rate }_{\mathrm{t}}\end{array}$ \\
\hline & $(1)$ & $(2)$ & $(3)$ & (4) \\
\hline Strong euro country $\mathrm{x}$ post-euro dummy & $\begin{array}{l}-0.005 \\
{[0.038]}\end{array}$ & $\begin{array}{l}-0.005 \\
{[0.008]}\end{array}$ & $\begin{array}{l}-0.003 \\
{[0.035]}\end{array}$ & $\begin{array}{l}-0.006 \\
{[0.009]}\end{array}$ \\
\hline Weak euro country x post-euro dummy & $\begin{array}{l}0.093 * \\
{[0.043]}\end{array}$ & $\begin{array}{c}0.008 \\
{[0.009]}\end{array}$ & $\begin{array}{c}0.061 \\
{[0.038]}\end{array}$ & $\begin{array}{c}0.007 \\
{[0.010]}\end{array}$ \\
\hline $\log (\text { firm } Q)_{t-1}$ (instrumented) & & $\begin{array}{c}0.133^{* *} \\
{[0.047]}\end{array}$ & & $\begin{array}{c}0.159 * * \\
{[0.046]}\end{array}$ \\
\hline Cash flow/assets $_{\mathrm{t}-1}$ & $\begin{array}{c}0.222 \\
{[0.164]}\end{array}$ & $\begin{array}{l}0.150 * * \\
{[0.027]}\end{array}$ & $\begin{array}{c}0.219 \\
{[0.162]}\end{array}$ & $\begin{array}{l}0.146^{* *} \\
{[0.027]}\end{array}$ \\
\hline Cash/assets $_{\mathrm{t}-1}$ & $\begin{array}{c}0.268 * * \\
{[0.079]}\end{array}$ & $\begin{array}{l}0.253 * * \\
{[0.031]}\end{array}$ & $\begin{array}{l}0.267 * * \\
{[0.077]}\end{array}$ & $\begin{array}{c}0.246^{* *} \\
{[0.031]}\end{array}$ \\
\hline Leverage $_{t-1}$ & $\begin{array}{l}-0.123 \\
{[0.064]}\end{array}$ & $\begin{array}{c}-0.134 * * \\
{[0.023]}\end{array}$ & $\begin{array}{c}-0.134^{*} \\
{[0.068]}\end{array}$ & $\begin{array}{c}-0.129 * * \\
{[0.023]}\end{array}$ \\
\hline $\log (\text { sales })_{\mathrm{t}-1}$ & $\begin{array}{c}0.042 \\
{[0.024]}\end{array}$ & $\begin{array}{c}-0.040 * * \\
{[0.005]}\end{array}$ & $\begin{array}{c}0.042 \\
{[0.024]}\end{array}$ & $\begin{array}{c}-0.041 * * \\
{[0.005]}\end{array}$ \\
\hline GDP growth $_{\mathrm{t}-1}$ & $\begin{array}{l}3.122 * * \\
{[0.665]}\end{array}$ & $\begin{array}{c}0.287 \\
{[0.244]}\end{array}$ & $\begin{array}{l}2.718 * * \\
{[0.638]}\end{array}$ & $\begin{array}{c}0.204 \\
{[0.243]}\end{array}$ \\
\hline $\log (\mathrm{GDP} / \text { capita })_{\mathrm{t}-1}$ & $\begin{array}{c}-0.876 * * \\
{[0.107]}\end{array}$ & $\begin{array}{c}0.014 \\
{[0.077]}\end{array}$ & $\begin{array}{c}-0.720 * * \\
{[0.142]}\end{array}$ & $\begin{array}{c}0.033 \\
{[0.076]}\end{array}$ \\
\hline $\begin{array}{l}\text { Relative change in domestic/ USD/ } \\
\text { exchange rate } \text { t }_{1-1}\end{array}$ & $\begin{array}{l}0.332 * \\
{[0.158]}\end{array}$ & $\begin{array}{l}0.162 * * \\
{[0.052]}\end{array}$ & $\begin{array}{c}0.227^{*} \\
{[0.109]}\end{array}$ & $\begin{array}{l}0.171 * * \\
{[0.053]}\end{array}$ \\
\hline $\begin{array}{l}\text { Absolute change in } \log (\text { firm } Q)_{t-1} \\
\quad \text { (instrument) }\end{array}$ & $\begin{array}{l}0.260 * * \\
{[0.065]}\end{array}$ & & $\begin{array}{l}0.257 * * \\
{[0.067]}\end{array}$ & \\
\hline $\begin{array}{l}\text { Absolute change in } \log (\text { industry } Q)_{t-1} \\
\text { (instrument) }\end{array}$ & $\begin{array}{l}-0.077 * \\
{[0.037]}\end{array}$ & & $\begin{array}{l}-0.074 * \\
{[0.038]}\end{array}$ & \\
\hline Change in short-term interest rate $\mathrm{t}_{\mathrm{t}}$ & & & $\begin{array}{c}0.646 \\
{[1.640]}\end{array}$ & $\begin{array}{l}-0.530 \\
{[0.400]}\end{array}$ \\
\hline Change in term-spread ${ }_{t}$ & & & $\begin{array}{c}2.167 \\
{[3.183]}\end{array}$ & $\begin{array}{l}-0.397 \\
{[0.537]}\end{array}$ \\
\hline $\begin{array}{l}\text { Short-term interest rate }{ }_{t-1} \\
\text { (instrument) }\end{array}$ & & & $\begin{array}{l}-0.064 \\
{[1.036]}\end{array}$ & \\
\hline $\begin{array}{l}\text { Term- } \text { spread }_{t-1} \\
\text { (instrument) }\end{array}$ & & & $\begin{array}{c}2.818 \\
{[3.042]}\end{array}$ & \\
\hline Year dummies and fixed firm-effects & YES & YES & YES & YES \\
\hline Adjusted $\mathrm{R}^{2}$ excluding fixed firm effects & 0.192 & 0.153 & 0.196 & 0.144 \\
\hline Number of observations & 4,664 & 4,664 & 4,664 & 4,664 \\
\hline P-value from Sargan-test & & 0.299 & & 0.379 \\
\hline $\begin{array}{l}\text { P-value from F-test: } \\
\text { Strong euro vs. weak euro firms }\end{array}$ & 0.000 & 0.190 & 0.036 & 0.200 \\
\hline
\end{tabular}




\section{Table 11 (continued)}

$\underline{\text { Panel B: Excluding France and Germany only }}$

\begin{tabular}{|c|c|c|c|c|}
\hline \multirow[b]{4}{*}{ Explanatory variable: } & \multicolumn{4}{|c|}{ 2SLS regressions } \\
\hline & \multicolumn{4}{|c|}{ Dependent variable: } \\
\hline & $\frac{\text { First stage }}{\log (\text { firm } Q)_{t-1}}$ & $\begin{array}{l}\text { Second stage } \\
\text { Investment rate }_{t}\end{array}$ & $\frac{\text { First stage }}{\log (\text { firm Q })_{\mathrm{t}-1}}$ & $\begin{array}{l}\text { Second stage } \\
\text { Investment rate }\end{array}$ \\
\hline & $(1)$ & $(2)$ & $(3)$ & $(4)$ \\
\hline Strong euro country $\mathrm{x}$ post-euro dummy & $\begin{array}{l}0.077 * \\
{[0.037]}\end{array}$ & $\begin{array}{l}-0.012 \\
{[0.008]}\end{array}$ & $\begin{array}{c}0.054 \\
{[0.034]}\end{array}$ & $\begin{array}{l}-0.009 \\
{[0.008]}\end{array}$ \\
\hline Weak euro country $\mathrm{x}$ post-euro dummy & $\begin{array}{l}0.187 * * \\
{[0.042]}\end{array}$ & $\begin{array}{c}0.003 \\
{[0.011]}\end{array}$ & $\begin{array}{c}0.136 * * \\
{[0.043]}\end{array}$ & $\begin{array}{c}0.008 \\
{[0.010]}\end{array}$ \\
\hline $\log (\text { firm Q })_{\mathrm{t}-1}$ (instrumented) & & $\begin{array}{c}0.130 * * \\
{[0.024]}\end{array}$ & & $\begin{array}{c}0.119 * * \\
{[0.042]}\end{array}$ \\
\hline Cash flow/assets $\mathrm{t}_{\mathrm{t}-1}$ & $\begin{array}{l}0.355^{* *} \\
{[0.130]}\end{array}$ & $\begin{array}{l}0.248 * * \\
{[0.026]}\end{array}$ & $\begin{array}{c}0.357 * * \\
{[0.128]}\end{array}$ & $\begin{array}{c}0.129 * * \\
{[0.024]}\end{array}$ \\
\hline Cash/assets $\mathrm{t}_{\mathrm{t}-1}$ & $\begin{array}{l}0.339 * * \\
{[0.058]}\end{array}$ & $\begin{array}{c}-0.120 * * \\
{[0.018]}\end{array}$ & $\begin{array}{l}0.349 * * \\
{[0.057]}\end{array}$ & $\begin{array}{c}0.246^{* *} \\
{[0.026]}\end{array}$ \\
\hline Leverage $_{t-1}$ & $\begin{array}{l}-0.060 \\
{[0.061]}\end{array}$ & $\begin{array}{c}-0.033 * * \\
{[0.004]}\end{array}$ & $\begin{array}{l}-0.061 \\
{[0.064]}\end{array}$ & $\begin{array}{c}-0.119 * * \\
{[0.018]}\end{array}$ \\
\hline $\log (\text { sales })_{\mathrm{t}-1}$ & $\begin{array}{c}0.005 \\
{[0.020]}\end{array}$ & $\begin{array}{c}0.195 \\
{[0.228]}\end{array}$ & $\begin{array}{c}0.007 \\
{[0.020]}\end{array}$ & $\begin{array}{c}-0.033 * * \\
{[0.004]}\end{array}$ \\
\hline GDP growth $_{t-1}$ & $\begin{array}{l}2.860 * * \\
{[0.880]}\end{array}$ & $\begin{array}{c}0.009 \\
{[0.080]}\end{array}$ & $\begin{array}{l}2.267 * * \\
{[0.843]}\end{array}$ & $\begin{array}{c}0.214 \\
{[0.225]}\end{array}$ \\
\hline $\log (\mathrm{GDP} / \text { capita })_{\mathrm{t}-1}$ & $\begin{array}{c}-1.008 * * \\
{[0.259]}\end{array}$ & $\begin{array}{c}0.099 * * \\
{[0.029]}\end{array}$ & $\begin{array}{c}-0.830 * * \\
{[0.245]}\end{array}$ & $\begin{array}{l}-0.003 \\
{[0.077]}\end{array}$ \\
\hline $\begin{array}{l}\text { Relative change in domestic/ USD } \\
\text { exchange rate } \text { ex-1 }\end{array}$ & $\begin{array}{l}-0.218^{*} \\
{[0.097]}\end{array}$ & $\begin{array}{l}-0.012 \\
{[0.008]}\end{array}$ & $\begin{array}{l}-0.234^{*} \\
{[0.098]}\end{array}$ & $\begin{array}{l}0.096 * * \\
{[0.029]}\end{array}$ \\
\hline $\begin{array}{l}\text { Absolute change in } \log (\text { firm } Q)_{t-1} \\
\text { (instrument) }\end{array}$ & $\begin{array}{c}0.192 * * \\
{[0.035]}\end{array}$ & & $\begin{array}{l}0.194 * * \\
{[0.036]}\end{array}$ & \\
\hline $\begin{array}{l}\text { Absolute change in } \log (\text { industry } Q)_{\mathrm{t}-1} \\
\text { (instrument) }\end{array}$ & $\begin{array}{l}-0.037 \\
{[0.025]}\end{array}$ & & $\begin{array}{l}-0.035 \\
{[0.025]}\end{array}$ & \\
\hline Change in short-term interest rate $\mathrm{t}_{\mathrm{t}}$ & & & $\begin{array}{l}2.944^{*} \\
{[1.172]}\end{array}$ & $\begin{array}{l}-0.545 \\
{[0.372]}\end{array}$ \\
\hline Change in term-spread ${ }_{t}$ & & & $\begin{array}{c}1.907 \\
{[2.658]}\end{array}$ & $\begin{array}{l}-0.262 \\
{[0.423]}\end{array}$ \\
\hline $\begin{array}{l}\text { Short-term interest rate } \mathrm{t}_{\mathrm{t}-1} \\
\text { (instrument) }\end{array}$ & & & $\begin{array}{l}-0.059 \\
{[1.427]}\end{array}$ & \\
\hline $\begin{array}{l}\text { Term-spread } \\
\text { (instrument) }\end{array}$ & & & $\begin{array}{c}1.546 \\
{[1.718]}\end{array}$ & \\
\hline Year dummies and fixed firm-effects & YES & YES & YES & YES \\
\hline Adjusted $\mathrm{R}^{2}$ excluding fixed firm effects & 0.192 & 0.160 & 0.166 & 0.160 \\
\hline Number of observations & 8,216 & 8,216 & 8,216 & 8,216 \\
\hline P-value from Sargan-test & & 0.504 & & 0.409 \\
\hline P-value from F-test: & & & & \\
\hline Strong euro vs. weak euro firms & 0.000 & 0.162 & 0.085 & 0.108 \\
\hline
\end{tabular}

